\title{
Bombacoideae, Byttnerioideae, Grewioideae and Helicterioideae (Malvaceae s.l.) in the Raso da Catarina Ecoregion, Bahia, Brazil
}

\author{
Jéssica Batista Lima ${ }^{1 *}$, Massimo Giuseppe Bovini ${ }^{\circledR}$ \& Adilva de Souza Conceição ${ }^{1} \mathbb{D}$ \\ ${ }^{1}$ Universidade do Estado da Bahia, Departamento de Educação, Programa de Pós-Graduação em \\ Biodiversidade Vegetal, Herbário HUNEB (Coleção Paulo Afonso), Campus VIII, Paulo Afonso, BA, Brasil \\ ${ }^{2}$ Instituto de Pesquisas Jardim Botânico do Rio de Janeiro, Diretoria de Pesquisas, Rio de Janeiro, RJ, Brasil \\ *Corresponding author: Jéssica Batista Lima, e-mail: jessiica.bl@hotmail.com
}

LIMA J.B., BOVINI M.G., CONCEIÇÃO A.S. Bombacoideae, Byttnerioideae, Grewioideae and Helicterioideae (Malvaceae s.l.) in the Raso da Catarina Ecoregion, Bahia, Brazil. Biota Neotropica. 19(3): e20180569. http://dx.doi.org/10.1590/1676-0611-BN-2018-0569

\begin{abstract}
This work presents a floristic survey of the subfamilies Bombacoideae, Byttnerioideae, Grewioideae and Helicterioideae (Malvaceae s.l.) in the Raso da Catarina Ecoregion (RCE), Bahia, Brazil. The samples analyzed were collected from September 2013 to May 2015. The analyses were supplemented with dried collections kept in the herbaria: ALCB, HRB, HUEFS, HUNEB, HST, IPA, PEUFR, R and RB. The identifications were based mainly on specialized bibliographies, protologues, types and herbaria collections. Ten genera and 22 species of the subfamilies were recorded, nine endemic to Brazil. Waltheria L. was the most representative genus with five species, followed by Ceiba Mill. and Melochia L. with three species each, Helicteres L., Luehea Willd., Pachira Aubl. and Pseudobombax Dugand presented two species each and other genera were represented by one species each. Among the species recorded, Luehea candicans Mart. represents a new record for the Caatinga biome. The species most commonly found in the study area were Helicteres velutina K.Schum., Melochia tomentosa L., Waltheria brachypetala Turcz., $W$. indica L. and W. rotundifolia Schrank. The taxonomic treatment includes identification key, descriptions, illustrations, photos, geographical distribution, reproductive phenology and comments about all studied species.
\end{abstract}

Keywords: biodiversity, Caatinga, morphology, semiarid, taxonomy.

\section{Bombacoideae, Byttnerioideae, Grewioideae e Helicterioideae (Malvaceae s.l.) na Ecorregião Raso da Catarina, Bahia, Brasil}

Resumo: Este trabalho apresenta o levantamento florístico das subfamílias Bombacoideae, Byttnerioideae, Grewioideae e Helicterioideae (Malvaceae s.l.) na Ecorregião Raso da Catarina, Bahia, Brasil. Os espécimes analisados foram coletados no período de setembro/2013 a maio/2015. As análises foram complementadas com coleções herborizadas depositadas nos herbários: ALCB, HRB, HUEFS, HUNEB, HST, IPA, PEUFR, R e RB. As identificações foram realizadas com base, principalmente, em bibliografias especializadas, protólogos, imagens de coleções-tipo e consultas às coleções dos herbários visitados. Foram registrados 10 gêneros e 22 espécies para as subfamílias, sendo nove endêmicas do Brasil. Waltheria L. foi o gênero mais representativo com cinco espécies, seguido por Ceiba Mill. e Melochia L. com três espécies cada, Helicteres L., Luehea Willd., Pachira Aubl. e Pseudobombax Dugand apresentaram duas espécies cada e os demais gêneros foram representados cada um por uma única espécie. Entre as espécies catalogadas, Luehea candicans Mart. é um novo registro para o bioma Caatinga As espécies mais frequentes na área de estudo foram Helicteres velutina K.Schum., Melochia tomentosa L., Waltheria brachypetala Turcz., $W$. indica L. e W. rotundifolia Schrank. O tratamento taxonômico inclui uma chave para a identificação, descrições, ilustrações, fotografias, dados de distribuição geográfica, fenologia reprodutiva e comentários sobre todas as espécies estudadas.

Palavras-chave: biodiversidade, Caatinga, morfologia, semiárido, taxonomia. 


\section{Introduction}

The family Malvaceae, as currently circumscribed, has a Cosmopolitan distribution, but is predominantly Pantropical, comprising about 250 genera and 4,200 species (Bayer \& Kubitzki 2003). There are about 73 genera and 783 species in Brazil, of which approximately 290 are distributed in the Northeast Region and 161 in the Caatinga, with more than $50 \%$ of the species that occur in the country being endemic (Bovini et al. 2015, BFG 2015).

In traditional classification systems, Malvaceae, Bombacaceae, Sterculiaceae and Tiliaceae were included in the order Malvales as distinct families (Dahlgren 1980, Takhtajan 1980, Cronquist 1988). However, in recent decades, morphological, anatomical, palynological and chemical studies (Judd \& Manchester 1997), associated with phylogenetic analyses based on molecular data (Alverson et al. 1999, Bayer et al. 1999, Nyffeler et al. 2005), have shown that the separation of these four families is inconsistent. For this reason, Bombacaceae, Sterculiaceae and Tiliaceae were circumscribed within Malvaceae s.l., a monophyletic group characterized by the presence of nectaries consisting of glandular trichomes located internally at the base of the calyx or, less commonly, on the petals or androgynophore (Judd \& Manchester 1997, Bayer et al. 1999, Vogel 2000, Judd et al. 2009).

Phylogenetic studies based on molecular data of Malvaceae s.l. recognized nine subfamilies. Of these, Bombacoideae includes the remnants of Bombacaceae, after the removal of two tribes, and along with Malvoideae form a well-sustained clade called Malvatheca. Byttnerioideae contains the tribes Byttnereae, Hermannieae, Lasiopetaleae and Theobromeae (cacau and allies of the family Sterculiaceae), and Grewioideae consists of the tribes Grewieae and Sparrmannie, previously treated in Tiliaceae. Together Byttnerioideae and Grewioideae form the Byttneriina clade. The subfamily Helicteroideae consists of the tribe Helictereae (formerly classified in Sterculiaceae) and Durioneae (formerly classified in Bombacaceae) (Alverson et al. 1999, Bayer et al. 1999, Bayer \& Kubitzki 2003, Baum et al. 2004).

The subfamilies of Malvaceae are distributed in tropical regions of the New and Old World, except for Tilioideae, which occurs in the Northern Hemisphere; Bombacoideae, which is mainly Neotropical but with some representatives in the tropics of the Old World; and Malvoideae, which occurs in temperate regions of all continents, but predominantly in tropical regions of the New World (Bayer \& Kubitzki 2003). In Brazil, the subfamilies are represented throughout the country and among all phytogeographic domains (Bovini et al. 2015). Many of these species are of great economic importance, such as cacau (Theobroma cacao L.) and cupuaçu (Theobroma grandiflorum (Willd. ex Spreng.) K.Schum.), which are used for food and medicine; and the paineiras [Ceiba speciosa (A.St.-Hil., A.Juss. \& Cambess.) Ravenna and C. pubiflora (A.St.-Hil.) K.Schum.] and carolina [Pachira aquatica Aubl.], which stand out as ornamentals. The African species Baobá (Adansonia digitata L.) is considered one of the most robust on the planet. Notable in natural ecosystems are the genera Luehea Willd., common in seasonal forests; Helicteres L. in the Cerrado and flooded areas; Triumfetta L. and Waltheria L., which have species considered invasive of crops; the barrigudas (Cavanillesia Ruiz \& Pav. e Ceiba Mill.) and embiruçus (Pseudobombax Dugand) in the Caatinga, which are important producers of fiber (Sampaio et al. 2005, Lorenzi \& Matos 2008, Souza \& Lorenzi 2012, Kinupp \& Lorenzi 2014).
Some taxonomic studies of the genera subordinate to these subfamilies include the reviews like Triumfetta L. (Lay 1950), Bombax L. (Robyns 1963), Ceiba Mill (Gibbs \& Semir 2003), Ayenia L., Byttneria Loefl., Rayleya Cristóbal and Helicteres L. (Cristóbal 1960, 1976, 1981, 2001), Melochia L. (Goldberg 1967, Rondón 2007) and Waltheria L. (Saunders 1995). Among floristic inventories are those for Argentina (Cristóbal 1998), Panama (Robyns 1964a,b, Robyns \& Cuatrecasas 1964) and Paraguay (Cristóbal 2007).

For Brazil, important taxonomic treatments of the families Bombaceae, Tiliaceae, Sterculiaceae and Malvaceae were performed by Saint-Hilaire (1825-1827) in Flora brasilice meridionalis and Schumann (1886) in Flora Brasiliensis. Other relevant studies treated these groups in lists or monographic studies of state flora, such as the Flora da Serra do Cipó (Esteves 1986); Flora de Mucugê (Cristóbal \& Tressens 1986); Flora do Pico das Almas (Cristóbal et al. 1995); Flora de Mirandiba (Amorim et al. 2009), Flora da Reserva Ducke (Vicentini \& Silva 1999, Esteves 2005); Flora de Grão-Mogol (Cristóbal 2006); Flora de São Paulo (Souza \& Esteves 2002, Duarte et al. 2007, Cruz \& Esteves 2009) and Flora de Sergipe (Amorim 2013). Also noteworthy are revisions of the genera Pseudobombax Dugand for Bahia (Carvalho-Sobrinho 2006), Eriotheca Schott \& Endl. in Brazil (Duarte 2010), Melochia L. in the Southeast Region (Gonçalez \& Esteves 2017), Malvaceae of Parque Estadual do Ibitipoca (Fernandes-Júnior \& Konno 2017) and Flora of the canga of the Serra dos Carajás, Pará (Fernandes-Júnior \& Cruz 2018). Nonetheless, there remains a great shortage of studies of these subfamilies in the Caatinga.

Despite the existence of studies about subfamilies from the Brazilian semiarid, regional studies on this family within the state of Bahia are scarce, especially those that include identification keys and morphological descriptions for the family. Considering the importance of the subfamilies in the Brazilian flora, and the gap of information regarding these groups in the Caatinga biome, this study aimed to elaborate a taxonomic study of subfamilies within the Raso da Catarina Ecoregion (RCE) in the state of Bahia and to provide information in support of the development of management plans for the conservation units of the Ecoregion.

\section{Material and Methods}

The Raso da Catarina Ecoregion (RCE) comprises an area of $30.800 \mathrm{~km}^{2}$, being one of the eight Ecoregions recognized for the Caatinga biome in Brazil. In the North-South direction it is narrow and elongated. In the North, West and East it is limited to the southern hinterland depression. The northeastern portion borders with the Borborema Plateau in the state of Pernambuco, and the southern part borders with hinterlands in the state of the Bahia. The Ecoregion is a sedimentary basin with a very flat relief, showing canyons formed by sandstone outcrops only in the western part. Altitudes above sea level vary from 400 to $600 \mathrm{~m}$ in the southern part (state of Bahia) and from 350 to $700 \mathrm{~m}$ in the northern part (Jatobá basin, state of Pernambuco). In the southern part (state of Bahia) most of the soils are composed of sand (deep, excessively drained, acid and very low fertility) and oxisol (deep, well drained, acid and low fertility) whereas in the northern part (Pernambuco) sandy soils prevail. Water availability is scarcein the region, except in the areas of the canyons. The predominant vegetation 
is woodland Caatinga in sandy soils, and thorny over crystalline soils (Velloso et al. 2002).

The climate of the Ecoregion is characterized as semiarid with average rainfalls of $650 \mathrm{~mm} /$ year in the southern part (state of Bahia), with rainy season from December to July. In the northern part (state of Pernambuco) the climate is drier with average rainfalls of 450 $\mathrm{mm} /$ year, with rainy season from January to April. Temperatures are very high, ranging from $24{ }^{\circ} \mathrm{C}$ to $30{ }^{\circ} \mathrm{C}$ (Velloso et al. 2002, Paes \& Dias 2008). The municipalities in this Ecoregion in the state of Bahia are: Canudos, Chorrochó, Cícero Dantas, Euclides da Cunha, Glória, Jeremoabo, Macururé, Paulo Afonso, Rodelas, Santa Brígida and Uauá. The Ecoregion includes six conservation units, five located in its southern part in the state of Bahia: Ecological Station Raso da Catarina, Environmental Preservation Area Serra Branca (EPASB), State Park of Canudos, Biological Station of Canudos, Private Reserve of Natural Heritage (PRNH) Farm Flor de Lis and Biological Reserve of Serra Negra, located in the northern part, in the state of Pernambuco (Velloso et al. 2002, Szabo et al. 2007).

This study was based on fieldwork carried out from September 2013 to May 2015 during random walks exploring most of the study area. Fieldwork expeditions focused mainly conservation units
(Figures 1,2) within the southern part of the Ecoregion, in the state of Bahia: Environmental Protection Area Serra Branca- EPASB (09'53'15.5" to $09^{\circ} 44^{\prime} 34.6^{\prime \prime} \mathrm{S}$ and $38^{\circ} 49^{\prime} 36.1^{\prime \prime}$ to $38^{\circ} 52^{\prime} 20.4^{\prime \prime} \mathrm{W}$ ), Biological Station of Canudos- BSC ( $09^{\circ} 55^{\prime} 58.6^{\prime \prime}$ to $09^{\circ} 58^{\prime} 25.2^{\prime \prime} \mathrm{S}$ and $38^{\circ} 57^{\prime} 32.2^{\prime \prime}$ to $\left.39^{\circ} 01^{\prime} 38.5^{\prime \prime} \mathrm{W}\right)$, Ecological Station of Raso da Catarina - ESRC $\left(09^{\circ} 33^{\prime} 13^{\prime \prime}\right.$ to $09^{\circ} 54^{\prime} 30^{\prime \prime} \mathrm{S}$ and $38^{\circ} 29^{\prime} 20^{\prime \prime}$ to $38^{\circ} 44^{\prime} 00^{\prime \prime}$ W), State Park of Canudos - SPC (0956'19.7' to 0954'32.4” S and $39^{\circ} 06^{\prime} 13.3^{\prime \prime}$ to $39^{\circ} 04^{\prime} 20.5^{\prime \prime} \mathrm{W}$ ), and PRNH Farm Flor de Lis $\left(10^{\circ} 50^{\prime} 14.1^{\prime \prime}\right.$ to $10^{\circ} 50^{\prime} 26.4^{\prime \prime} \mathrm{S}$ and $38^{\circ} 31^{\prime} 46.4^{\prime \prime}$ to $\left.38^{\circ} 31^{\prime} 34.7^{\prime \prime} \mathrm{W}\right)$ (Vieira et al. 2015).

Herborization of specimens followed Fosberg \& Sachet (1965), and Mori et al. (1989), and observations on soil types followed Tricart (1972), and Sampaio (1995). All collected specimens were deposited at HUNEB herbarium (Paulo Afonso Collection), and duplicates were sent to herbaria in the state of Bahia. Additional herbarium specimens from Brazilian herbaria were analyzed (ALCB, HRB, HUEFS, HUNEB, IPA, PEUFR, R and RB, acronyms according to Thiers 2018 (continuously updated, Appendix 1), and in the herbaria HST, acronyms according to the Brazilian network of herbaria (SBB 2018). Identifications were made based on specialized literature (e.g., Robyns 1963, Robyns \& Cuatrecasas 1964, Cristóbal 2001, Du Bocage \& Sales 2002, Tschá
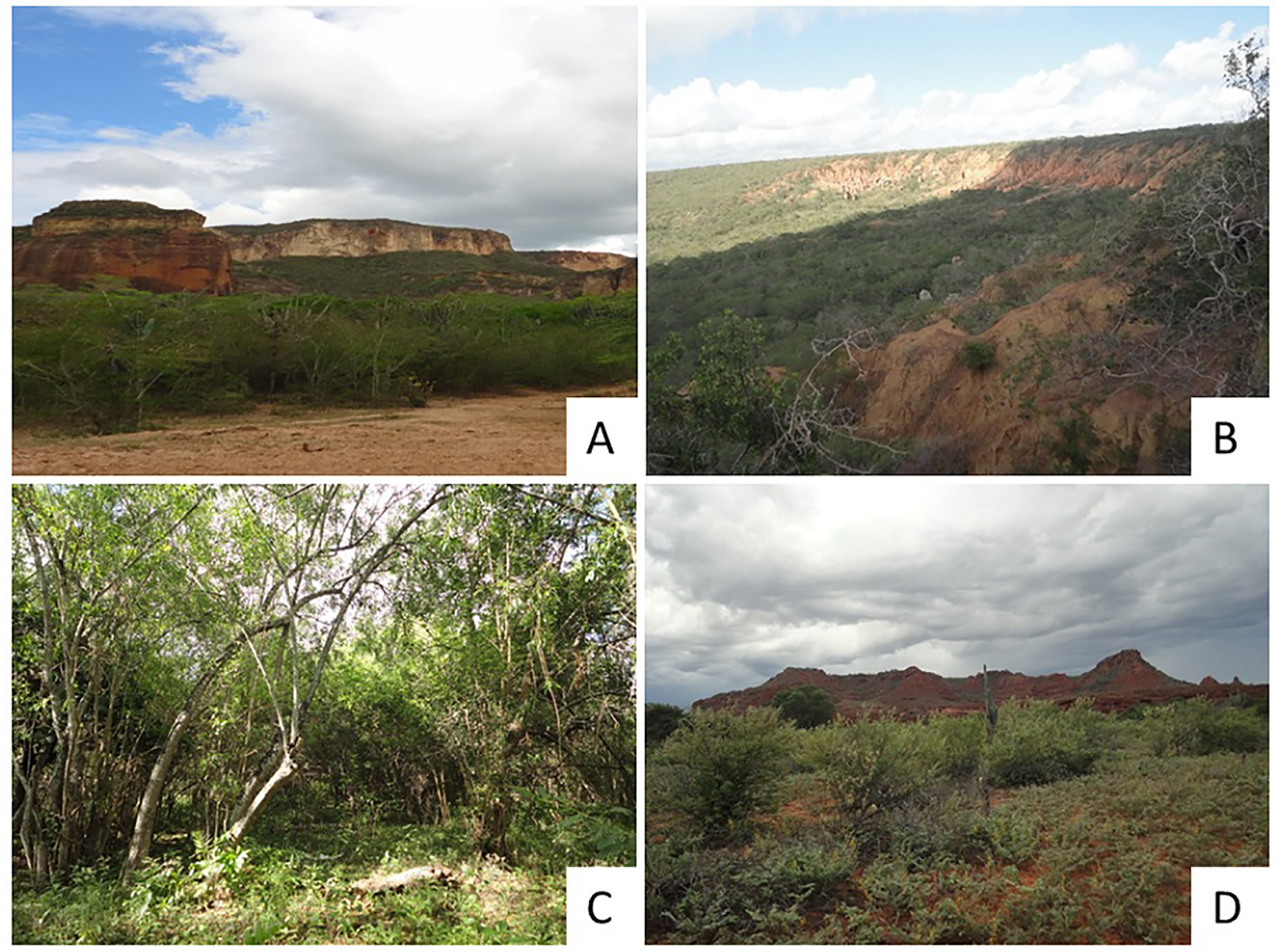

Figure 1. Units of Conservation of the Raso da Catarina Ecoregion, part Bahia, Brazil. A. Environmental Protection Area Serra Branca; B. Ecological Station Raso da Catarina; C. PRNH Farm Flor de Lis; D. Biological Station of Canudos. Photos by J.B. Lima. 


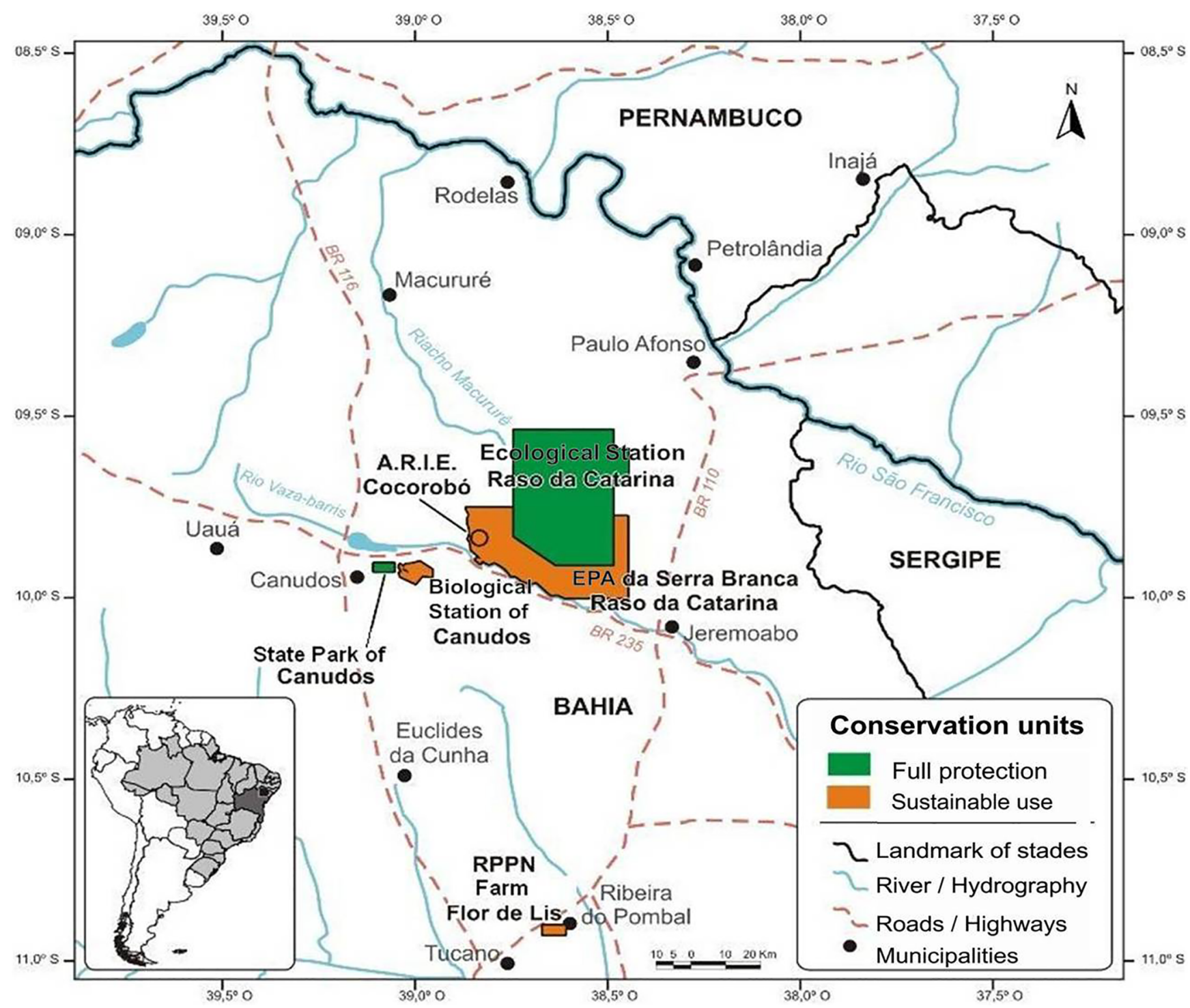

Figure 2. Location of conservation units of the Raso da Catarina Ecoregion, state of Bahia, Brazil (Varjão et al. 2013, modified).

et al. 2002, Gibbs \& Semir 2003, Carvalho-Sobrinho 2006, Cristóbal 2006, Duarte 2006, Róndon \& Campos 2006, Cruz \& Esteves 2009, Rondón 2009 and Carvalho-Sobrinho et al. 2014), protologues and images of type specimens. Morphological descriptions followed Harris \& Harris (2001) and Gonçalves \& Lorenzi (2011). The taxonomic treatment includes morphological descriptions, an identification key, and comments on distribution, ecology and taxonomy of all studied species.

\section{Results and Discussion}

In the RCE, the subfamilies Bombacoideae, Byttnerioideae, Grewioideae and Helicterioideae were represented by a total of 22 species distributed among 10 genera (Figure 3). Waltheria L. was the most represented genus with five species, followed by Ceiba Mill. and Melochia L. with three species each. Helicteres L., Luehea Willd., Pachira Aubl. and Pseudobombax Dugand were each represented by two species, while the remaining genera were represented by a single species each. The most frequently encountered species in the study were Helicteres velutina K.Schum., Melochia tomentosa L., Waltheria brachypetala Turcz., $W$. indica L. and $W$. rotundifolia Schrank. These species grow in subshrub and forest Caatinga environments associated with sandy soils, the latter two are also observed in anthropic areas. The species of Luehea were rare in RCE, being represented by a single specimen.

Among the species recognized for RCE, nine are endemic to Brazil, Luehea candicans Mart. represents a new record for the Caatinga biome. Pseudobombax parvifolium Carv.-Sobr. \& L.P.Queiroz, Pseudobombax simplicifolium A.Robyns, Waltheria brachypetala Turcz. and Ayenia hirta A.St.-Hil. \& Naudin are endemic to the Caatinga, the last of which occurs exclusively in the state of Bahia (Robyns 1963, CarvalhoSobrinho \& Queiroz 2010, Duarte 2015a, b, c, Esteves 2015a, b, c, f). Some species such as Melochia tomentosa L., Waltheria indica L. and Luehea paniculata Mart. have medicinal, agricultural and forage potential. Species of the subfamily Bombacoideae are ornamental and serve in fiber production (Sampaio et al. 2005, Lorenzi \& Matos 2008, Kinupp \& Lorenzi 2014). 


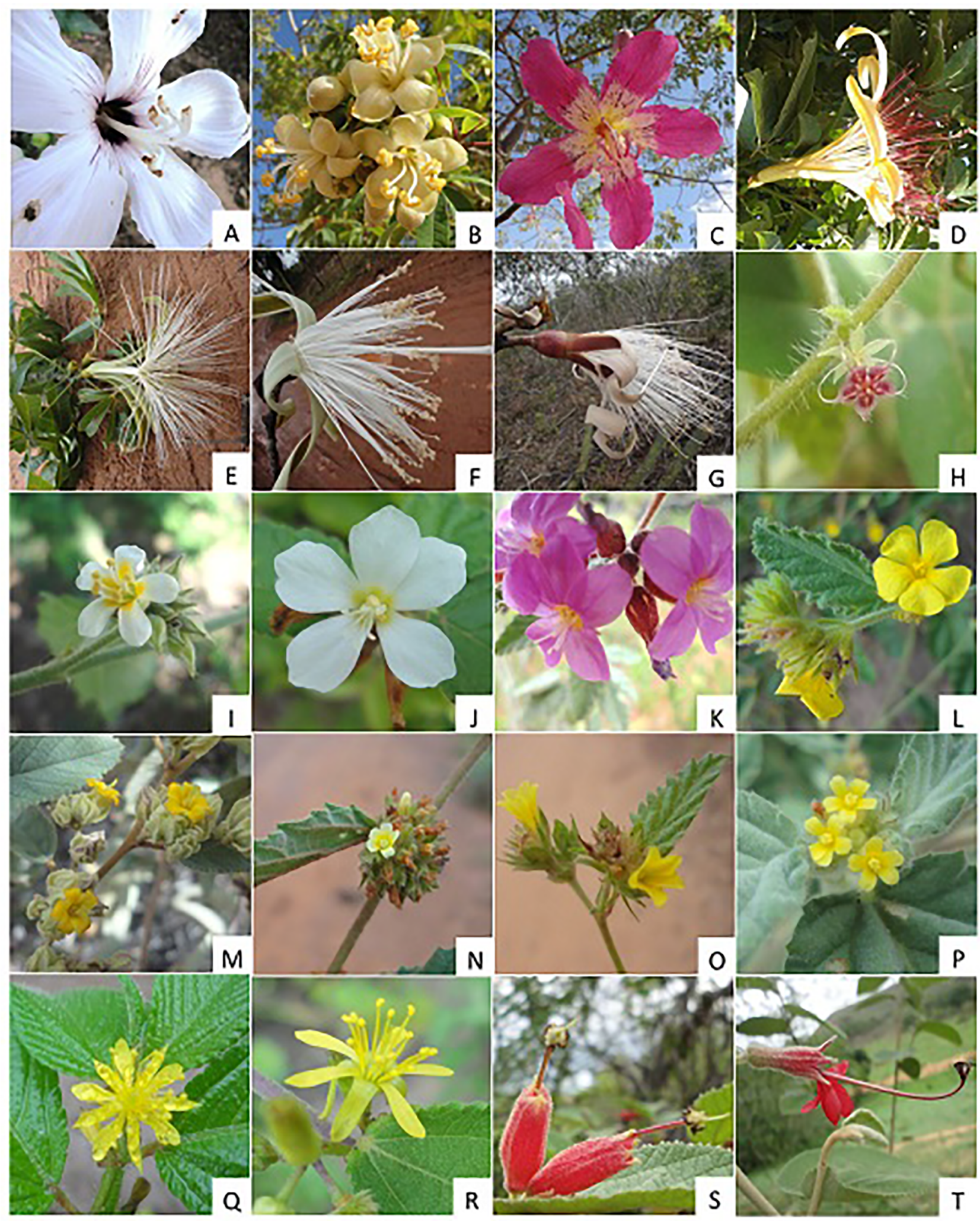

Figure 3. Representatives of the subfamilies Bombacoideae, Byttnerioideae, Grewioideae and Helicterioideae in the Raso da Catarina Ecoregion. A. Ceiba glaziovii; B. Ceiba pentandra; C. Ceiba pubiflora; D. Pachira aquatica; E. Pachira endecaphylla; F. Pseudobombax parvifolium; G. Pseudobombax simplicifolium; H. Ayenia hirta; I. Melochia betonicifolia; J. Melochia illicioides; K. Melochia tomentosa; L. Waltheria albicans; M. Waltheria brachypetala; N. Waltheria indica; O. Waltheria operculata; P. Waltheria rotundifolia; Q. Corchorus hirtus; R. Triumfetta semitriloba; S. Helicteres eichleri; T. Helicteres velutina. Photos by J.B. Lima. 
Identification key to the species of Bombacoideae, Byttnerioideae, Grewioideae and Helicterioideae from RCE, Bahia, Brazil

1. Trees.

2. Leaves compound.

3. Trunk and branches aculeate. Flowers with 5 stamens.

4. Leaflets with margin entire. Petals without macules

1.2. Ceiba pentandra (cultivaded)

4'. Leaflets with margin slightly serrate. Petals with macules.

5. Petals white, presence of entire appendages at the base of the staminal tube

1.1. Ceiba glaziovii

5'. Petals lilac to pink, presence of bifid appendages at the base of the staminal tube

1.3. Ceiba pubiflora

3'. Trunk and branches inerms. Flowers with more than 5 stamens. 6. Staminal tube bigger than $5 \mathrm{~cm}$ long, originating 10 phalanges.

7. Stamens white at the base and vinaceous on apex. Seeds 25-43 $\times 17-22 \mathrm{~mm}$, angulate

1.4. Pachira aquatica (cultivaded)

7'. Stamens white. Seeds 6-8×5-6 mm, subglobose ........ 1.5. Pachira endecaphylla

6'. Staminal tube smaller than $3 \mathrm{~cm}$ long, originating free filaments.

8. Branches without brachyblast. Leaves 5-7 foliolate. Staminal tube pubescent. Capsule $8.5-9 \times 4.5-5 \mathrm{~cm}$, elliptic. Seeds subreniform, brown with inconspicuous macules slightly darker

1.6. Pseudobombax parvifolium 8'. Branches with brachyblast. Leaves 1(-3) foliolate. Staminal tube glabrous. Capsule $11-13 \times 1.8-2.5 \mathrm{~cm}$, oblong. Seeds piriform to subglobose, light brown, without macules 1.7. Pseudobombax simplicifolium

2'. Leaves simple.

9. Solitary flower, terminal

3.2. Luehea candicans

9'. Inflorescence paniculate, terminal and axillary

3.3. Luehea paniculata

1'. Subshrub to shrub.

10. Flowers with 5 stamens.

11. Ovary with 5-6 locules.

12. Androgynophore present. Petals with claw that project to a base of the androgynophore and appendages on the blade. Anters 3-thecate. Capsule subglobose, aculeate ...... 2.1. Ayenia hirta 12'. Androgynophore absent. Petals flat, not divided into claw and blade without appendages. Anters bitecate. Capsule pyramidal, not aculeate.

13. Petals white.

14. Petals up to $8 \mathrm{~mm}$ long. Capsule pyramidal 2.2. Melochia betonicifolia

14'. Petals 12-15 mm long. Capsule conic-globose

2.3. Melochia illicioides

13'. Petals lilac 2.4. Melochia tomentosa

11 '. Ovary with 1 locule.

15. Branches with simple trichomes. Inflorescences in helicoidal glomerule, terminal. Capsule with dehiscence operculate

2.8. Waltheria operculata $15^{\prime}$. Branches with predominantly stellate trichomes. Inflorescences in glomerule not helicoidal, axillary. Capsule with dehiscenceapical, indehiscent or loculicidal.

16. Branches slightly flexuose, trichomes stellate stipitated. Leaves lanceolate slightly falciform

2.6. Waltheria brachypetala

16'. Branches not flexuose, trichomes stellate sessile. Leaves ovate, elliptic or orbicular.

17. Branches with glandular trichomes. Petals $8-10 \mathrm{~mm}$ long 2.5. Waltheria albicans

17'. Branches without glandular trichomes. Petals smaller than $8 \mathrm{~mm}$ long.

18. Leaves ovate-elliptic, not canescent, green discolorous 2.7. Waltheria indica

18'. Leaves orbicular, canescent, green concolorous ......... 2.9. Waltheria rotundifolia

10'. Flowers with more than 5 stamens.

19. Flowers with 10 stamens. Staminodes present. Capsule spirallate.

20. Branches and leaves tomentose. Pedicel without nectaries. Petals included, reduced to flabeliform claw. Androgynophore erect, 3-4 cm long 4.1. Helicteres eichleri 20 '. Branches and leaves velutinous. Pedicel with 1-3 nectaries. Petals well developed, longer than the calyx. Androgynophore curved, 6-8 cm long 4.2. Helicteres velutina

19'. Flowers with more than 10 stamens. Staminodes absent. Capsule not spirallate.

21. Sepals cucullate. Gonophore with glands elliptic at the base of ovary. Nucaceous globose, indehiscent, with uncinate spine

3.4. Triumfetta semitriloba

21'. Sepals flat. Androgynophore without glands. Capsule elongate-flattened, dehiscence longitudinal, without uncinate spine

3.1. Corchorus hirtus

\section{Taxonomic Treatment}

\section{Bombacoideae Burnett}

Trees. Leaves compound, venation reticulate. Flowers actinomorphic, hermaphrodite, diclamid or triclamid, solitary or in inflorescence axillary, terminal or oppositifolious. Calyx gamosepalous. Corolla with five petals, free or fused at the base and adnate at the base of staminal tube. Stamens five to numerous, fused at the base, forming a staminal tube. Ovary super; numerous ovules per locule; placentation axile. Fruit capsule.

Consisting of 27 genera and 250 species, Bombacoideae is mainly Neotropical, with some representatives in the tropics of the Old World (Bayer \& Kubitzki 2003). In the RCE, the subfamily is represented by three genera and seven species.

1.1. Ceiba glaziovii (Kuntze) K.Schum., Bot. Jahresber. (Just) 26(1): 343. 1900. Iconography: Du Bocage \& Sales (2002: 126). Figures 3A; 4A-C

Popular name: barriguda.

Tree 6-10 m tall. Trunk tumescent, aculeate, grey, with green longitudinal streaks only in young individuals; branches aculeate; 
brachyblast absent. Stipules deciduous, not observed. Leaves alternatespirallate, digitate, 5 leaflets; petiole $5-10 \mathrm{~cm}$ long, glabrous; petiolule 1.5-4 mm long, glabrous; leaflets $2.5-11.5 \times 1.5-5.5 \mathrm{~cm}$, ellipticlanceolate, green, discolorous, membranaceous to chartaceous, base acute, apex acute-acuminate, margin slightly serrate at the apical portion, both surfaces glabrous. Inflorescence cymose, with up to three flowers or sometimes solitary flowers, axillary and terminal; pedicels 1.2-2 cm long., glabrous; bracteoles 3. 3-4 mm long, rounded, green, glabrous, deciduous; calyx $1.5-2 \mathrm{~cm}$ long, campanulate, green, 3-5 lobed, apex irregular, externally glabrous, internally glabrous at the base and sericeous at the apex, without glands at the base; petals $1.8-7.5 \times 1.8-3.0 \mathrm{~cm}$, obovate, white with macules purple to vinaceous in the base, externally sericeous, internally glabrous on the base and sericeous on the apex; stamens 5, white, fused until half of, staminal tube, 1-3 cm long, glabrous, 5 appendages villous entire at the base of staminal tube, free parts of stamens $2-3 \mathrm{~cm}$ long, anthers 4-thecal, white, sinuose, rimose, basifixed; ovary 5-6×4-5 mm, subconic, glabrous, 5 locules, numerous ovules per locule; styles $5.6-6 \mathrm{~cm}$ long, glabrous, stigmas ellipsoid, rose. Capsule 7-12.5 ×5-8 cm, elliptic, dehiscence longitudinal, glabrous, coriaceous, cotton-fiber white abundant, calyx persistent; seeds 6-7×4-6 mm, globose, dark brown, without macules or streaks.

Specimens examined: BRAZIL, BAHIA: Jeremoabo, APA Serra Branca, Trilha do tanque de dentro, 0951'56.3"S 38 38'41.7"W 469m, 22.VIII.2008, fl., M.V. Romão et al. 268 (HUNEB); Fazenda Serra Branca, 0953'35.8"S 38 40'27.9"W 404m, 18.IX.2008, fl., M.V. Romão et al. 307 (HUNEB); Fazenda Serra Branca, 0953'51.5"S 3840'48.7"W 130m, 30.X.2008, fr., M.V. Romão et al. 387 (HUNEB); Caminho da

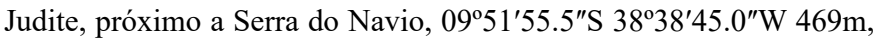
03.XI.2011, fl., J.B. Lima et al. 03 (HUNEB); 04.IX.2012, fl., J.B. Lima et al. 64 (HUNEB); 20.I.2015, fr., J.B. Lima et al. 600 (HUNEB); Povoado Brejinho 1002'32.0"S 38²1'44.2"W 307m, 31.VII.2014, fl., J.B. Lima et al. 460 (HUNEB); Povoado Brejinho, próximo a casa verde $10^{\circ} 02^{\prime 2} 26.7^{\prime \prime S} 38^{\circ} 21^{\prime} 42.9^{\prime \prime} \mathrm{W} 309 \mathrm{~m}, 25 . X I .2014$,fr., J.B. Lima et al. 573, 576 (HUNEB); Entre Jeremoabo e Canudos, $10^{\circ} 04^{\prime} 07^{\prime \prime} \mathrm{S} 38^{\circ} 28^{\prime} 21^{\prime \prime} \mathrm{W}$ 297m, 27.VI.2072, bot., R.M. Santos et al. 1664, 1665 (HUEFS); Paulo Afonso, Povoado Arrastapé, 09³0'49.2"S 38 16 $16^{\prime} 55.3^{\prime \prime} \mathrm{W} 300 \mathrm{~m}$, 25.IX.2013, fl., J.B. Lima et al. 107 (HUNEB); Povoado Bogó, 09³9'14.5"S 38 16'08.1"W 326m, 01.IX.2014, fl., J.B. Lima et al. 523 (HUNEB); Ribeira do Pombal, Fazenda Cassussu, 1047'25.7"S 3834'43.7"W 209m, 09.VIII.2014, fl., J.B. Lima et al. 485 (HUNEB).

Endemic to the Northeast Region of Brazil, Ceiba glaziovii occurs only in the states of Bahia, Ceará, Paraíba, Pernambuco, Rio Grande do Norte and Sergipe, in the areas of Caatinga, Cerrado and Atlantic Forest (Gibbs \& Semir 2003, Duarte 2015a). In RCE it was collected in the Environmental Protection Area Serra Branca (EPASB), municipality of Jeremoabo, and in the municipalities of Ribeira do Pombal and Tucano, mainly in areas of preserved Caatinga

The species is recognized by its intumescent trunk; petals white with purple macules and externally villous; and by the presence of five appendages at the base of the staminal tube. It flowers from July to October and fruits from September to November. According to Sampaio et al. (2005), C. glaziovii has medicinal, ornamental and apicultural potential.
1.2. Ceiba pentandra (L.) Gaertn., Fruct. Sem. P1. 2: 244. 1791. Figures 3B; 4D-F

Popular names: samaúma, barriguda-falada.

Tree 3-8 m tall. Trunk not tumescent, aculeate, green, with green longitudinal streaks; branches aculeate; brachyblast absent. Stipules deciduous, not observed. Leaves alternate-spirallate, digitate; petiole $3.5-13.9 \mathrm{~cm}$ long, glabrous; petiolules $1.5-3 \mathrm{~mm}$ long, glabrous; leaflets 5-8, 3.4-12.3 ×1.3-3.4 cm, elliptic-lanceolate, green, discolorous, membranaceous to chartaceous, base acute, apex acuminate, margin entire, both surfaces glabrous. Inflorescence cymose fasciculated, with 5-10 flowers axillary and terminal; pedicels $1.3-3 \mathrm{~cm}$ long, glabrous; bracteoles absent; calyx 1-1.3 cm long, campanulate, green, 4-5 lobed, apex irregular, externally glabrous, internally sericeous, without glands at the base; petals $2.5-3 \times 1.3-1.7 \mathrm{~cm}$, obovate, white, without macules, externally sericeous, internally glabrous on the base and sericeous on the apex; stamens 5, white, fused at the base, staminal tube ca. $3 \mathrm{~mm}$ long, glabrous, without appendages at the staminal tube, free parts of stamens 2-2.3 cm long, anthers 4-thecal, beige, sinuose, rimose, dorsifixed; ovary 5-6 $\times 3-4 \mathrm{~mm}$, piriform, glabrous, 5 locules, numerous ovules per locule; styles $2-2.5 \mathrm{~cm}$ long, glabrous, stigmas ellipsoid, yellow. Capsule $8-13 \times 2.8-3.7 \mathrm{~cm}$, elliptic, dehiscence longitudinal, glabrous, coriaceous, cotton-fiber white abundant, calyx persistent; seeds 5-6×5-6 mm, globose, blackened, without macules and streaks.

Specimens examined: BRAZIL, BAHIA: Paulo Afonso, Vila Matias, 09²6'56.1"S 38¹4'19.0"W 326m, 16.IV.2014, fr., J.B. Lima et al. 301 (HUNEB); Vila Matias, 09²6'56.1"S 38¹4'19.0"W 326m, 15.X.2014, fl., J.B. Lima et al. 540 (HUNEB); Praça entre a $1^{\text {a }}$ cia do exército e o anexo da UNEB, $09^{\circ} 24.235^{\prime} \mathrm{S} 38^{\circ} 12.772^{\prime} \mathrm{W} 215 \mathrm{~m}$, 26.VIII.2014, fl.; fr., J.B. Lima et al. 522 (HUNEB); Glória, estrada em direção a orla, $09^{\circ} 20^{\prime} 46.9^{\prime \prime} \mathrm{S} 38^{\circ} 15^{\prime} 24.5^{\prime \prime} \mathrm{W} 273 \mathrm{~m}$, fr., J.B. Lima et al. 306 (HUNEB).

With pantropical distribution, C. pentandra was possibly introduced in Asia and the Pacific (Gibbs \& Semir 2003). In the Brazil it is found in the states of Acre, Pará, Roraima and Maranhão in the areas of Amazon Rainforest (Duarte 2015a). In the RCE the species is only grown in squares and residences of Paulo Afonso and Glória.

The species differs from its congeners in the study area by having 5-8 foliate leaves; fasciculate inflorescence; white petals without macules and measuring less than $5 \mathrm{~cm}$ long; and by the absence of appendages at the base of the staminal tube. It was collected with flowers in August and October, and was fruiting throughout almost all year. Ceiba pentandra possesses ornamental, apicultural, food and fiber potential (Sampaio et al. 2005, Kinupp \& Lorenzi 2014).

1.3. Ceiba pubiflora (A.St.-Hil.) K.Schum., Fl. Bras. (Martius) 12(3): 213. 1886. Iconography: Gibbs \& Semir (2003: 277), Duarte (2006: 52). Figure $3 \mathrm{C}$

Tree 6-8 m tall. Trunk not tumescent, aculeate, grey, with green longitudinal streaks; branches aculeate; brachyblast absent. Stipules deciduous, not observed. Leaves alternate-spirallate, digitate; petiole $4.8-9.2 \mathrm{~cm}$ long, glabrous; petiolules $0.5-1.2 \mathrm{~mm}$ long, glabrous; leaflets 5, 3.5-14.8 $\times 1.1-5.2 \mathrm{~cm}$, elliptic-lanceolate, green, discolorous, membranaceous to chartaceous, base acute, apex acute-acuminate, margin slightly serrate, both surfaces glabrous. Inflorescence cymose, 
with until 5 flowers, axillary and terminal; pedicels $1.5-2 \mathrm{~cm}$ long, glabrous; bracteoles 3, deciduous, 3-5 mm long, ovate, green, glabrous; calyx 1.4-2 cm long, campanulate, green, 3-4 lobed, apex irregular, externally glabrous, internally sericeous on the base and glabrous on the apex, without glands at the base; petals $2.3-8.7 \times 1.5-3 \mathrm{~cm}$, obovate to spatulate, lilac to pink with alb base and macules purple to vinaceous, externally sericeous, internally glabrescent on the base and sericeous on the apex; stamens 5, white at the base and pink at apical half, fused until a half of, staminal tube, 1.5-1.8 cm long, glabrous, 5 bifid appendages villous on the base of staminal tube, free parts of stamens 2.8-4.5 cm long, anthers 4-thecal, white, sinuose, rimose, basifixed; ovary $8-10 \times 4-5 \mathrm{~mm}$, subconic, glabrous, 5 locules, numerous ovules per locule; styles 5-6 cm long, glabrous, stigmas globose, pink. Fruit not seen.

Specimens examined: BRAZIL, BAHIA: Paulo Afonso, Bairro $\mathrm{BNH}$, próximo a área do erxército, 09²3'38.4"S 38 $13^{\circ} 44.9^{\prime \prime} \mathrm{W}$ 252m, 17.III.2014, fl., J.B. Lima et al. 190 (HUNEB); Povoado Juá, $09^{\circ} 26^{\prime} 22.7^{\prime \prime} \mathrm{S} 38^{\circ} 25^{\prime} 16.7^{\prime \prime} \mathrm{W} 371 \mathrm{~m}, 09$. V.2014, fl., J.B. Lima et al. 350 (HUNEB).

Ceiba pubiflora occurs in Argentina (Missiones), Paraguay and Brazil; in Brazil it is present in the Northeast (Bahia), Central-West (Distrito Federal, Goiás, Mato Grosso do Sul, Mato Grosso) and Southeast (Espírito Santo, Minas Gerais, Rio de Janeiro, São Paulo) regions, in environments of Caatinga, Cerrado and Atlantic Forest (Gibbs \& Semir 2003, Duarte 2015a). It was introduced in the RCE as an ornamental species.

The species is easily recognized by having flowers with lilac to pink-colored petals with white base and purple to vinaceous macules; and by the presence of five bifid appendages in the base of the staminal tube. It flowers from March to May, and has not been found with fruits.

1.4. Pachira aquatica Aubl., Hist. Pl. Guiane 2: 726. 1775. Iconography: Robyns (1963: 235), Du Bocage \& Sales (2002: 132). Figure 3D Popular name: carolina.

Tree 6-14 m tall. Trunk not tumescent, inermous, grey, without green longitudinal streaks; branches inermous; brachyblast absent. Stipules 4-5 mm long, deltoid, deciduous. Leaves alternate-spirallate, digitate; petiole $4.5-14.7 \mathrm{~cm}$ long, glabrous; petiolules $0.3-2.0 \mathrm{~mm}$ long, glabrous; leaflets 5-7, 5.4-23.5 $\times 2.1-9.8 \mathrm{~cm}$, oblong-lanceolate to obovate, green, discolorous, semi-coriaceous, base acute, apex acuminate to obtuse, margin entire to slightly sinuose, both surfaces glabrous. Inflorescence cymose 2-3 flowers, usually flowers solitary, axillary and terminal; pedicels $1.5-3 \mathrm{~cm}$ long, glabrescent with stellate trichomes, ferruginous; bracteoles 3 , deciduous; calyx $1.2-1.8 \mathrm{~cm}$ long, campanulate, green, apex truncate, sometimes slightly 4-5 lobed, containing 5 pink glands at the base, externally pubescent, internally sericeous; petals $23-28 \times 0.9 \times 1.5 \mathrm{~cm}$, linear-lanceolate, intenally white, externally beige to light brown on the margin, both surfaces pubescent; stamens 200-230, white at the base and vinaceous on apex, fused until a half, staminal tube 7-9 $\mathrm{cm}$ long, pubescent, tube with two verticil, external verticil divided into 10 phalanges with $1.3-2 \mathrm{~cm}$ long, internal verticil divided into 5 phalanges, free parts of stamens $7.5-9 \mathrm{~cm}$ long, appendages absent, anthers monothecate, vinaceous, curved, rimoses, dorsifixed; ovary 6-7×5-6 mm, piriform, 5 costate, pubescent, 5 locules, numerous ovules per locule; styles $22.5 \mathrm{~cm}$ long, pubescent, white with apex pink to purple, stigmas 5 lobed, rose. Capsule $14-19.6 \times 9-10 \mathrm{~cm}$, subglobose to oblong-elliptic, dehiscence longitudinal, puberule, woody, without cotton-fiber, calyx not persistent; seeds $25-43 \times 17-22 \mathrm{~mm}, 3-4$ angular, white, with streaks.

Specimens examined: BRAZIL, BAHIA: Ribeira do Pombal, alto do Santo Antônio, em direção a PRNH Flor de Lis, 1050'02.1"S $38^{\circ} 31^{\prime} 32.0^{\prime \prime} \mathrm{W} 241 \mathrm{~m}, 17 . \mathrm{I} .2014$, fl.; fr, J.B. Lima et al. 174 (HUNEB); Canudos, estrada saindo da base 1 da EBC, próximo a casa de Rute e Tiago, 0954'52.0"S 3900'28.5"W 459m, 27.III.2014, fl.; fr, J.B. Lima et al. 255 (HUNEB).

Pachira aquatica occurs predominantly in Central and South America (Robyns 1963). In Brazil it is present in the states of Acre, Amazonas, Pará and Maranhão, in the Amazon Rainforest (Duarte $2015 b)$. In the RCE the species is common in the city squares of several municipalities.

The species can be recognized by its flowers having a long stamen tube; external verticil divided into ten phalanges; white stamens with a vinaceous apical half; and by 3-4 angular, striated seeds measuring $25-43 \times 17-22 \mathrm{~mm}$. The species flowers and fruits throughout the year. The species has ornamental, food and fiber potential (Sampaio et al. 2005, Kinupp \& Lorenzi 2014).

1.5. Pachira endecaphylla (Vell.) Carv.-Sobr., Taxon 62(4): 816. 2013. Iconography: Schumann (1886: 45). Figures 3E; 4G-J

Tree 10-12 m tall. Trunk not tumescent, inermous, green, with green longitudinal streaks inconspicuous; branches inermous; brachyblast absent. Stipules deciduous, not observed. Leaves alternate-spirallate, digitate; petiole 7-15 cm long, glabrous; leaflets 7-10, subsessile, $7-20 \times 2-5.8 \mathrm{~cm}$, oblong to lanceolate, green, discolorous, coriaceous, base attenuate decurrent, apex acute-acuminate, margin entire slightly sinuose, both surfaces glabrous. Flowers solitary, axillary, clustered at the apex of branches; pedicels 1-1.5 cm long, glabrescent with trichomes simple, ferruginous, sparse; bracteoles 3, deciduous; calyx $1.2-1.5 \mathrm{~cm}$ long, campanulate, green, apex truncate, slightly 5 lobed, containing 5 rose glands at the base, externally glabrescent, internally sericeous; petals $18-20.5 \times 1-1.5 \mathrm{~cm}$, linear-lanceolate, beige greenish, both as surfaces pubescent; stamens 125-150, white, fused until a half, staminal tube, 7-9 cm long, pubescent, tube with one verticil, divided into 10 phalanges with $1.5-2 \mathrm{~cm}$ long, free parts of stamens $5.2-7.5 \mathrm{~cm}$ long, appendages absent, anthers monothecate, beige, linear, rimose, basifixed; ovary $4-5 \times 4-5 \mathrm{~mm}$, piriform, not costate, pubescent, 5 locules, numerous ovules per locule; styles $15 \mathrm{~cm}$ long, pubescent, white, stigmas 5 lobed, white. Capsule $17-21 \times 4.5-5 \mathrm{~cm}$, oblongelliptic, dehiscence longitudinal, glabrous, woody, cotton-fiber light brown, calyx persistent; seeds $6-8 \times 5-6 \mathrm{~mm}$, subglobose, black pits, with 4 streaks beige salient, leaving from the same point.

Specimens examined: BRAZIL, BAHIA: Jeremoabo, APA Serra Branca, estrada do Quelés, próximo a casa de Antônio Rouxinho, 09'57'30.3"S 38²6'20.0"W 504m, 03.IX.2012, fr, J.B. Lima et al. 52 (HUNEB); Povoado Brejinho, 1002'26.6"S 38 $21^{\prime} 42.8^{\prime \prime} \mathrm{W} 308 \mathrm{~m}$, 08.III.2014, fl., J.B. Lima et al. 189 (HUNEB); Povoado Brejinho $10^{\circ} 02^{\prime} 32.0^{\prime \prime} \mathrm{S} 38^{\circ} 21^{\prime} 44.2^{\prime \prime} \mathrm{W} 307 \mathrm{~m}, 15$. V.2014,fr., J.B. Lima et al. 384 (HUNEB); Povoado Brejinho, próximo a casa verde $10^{\circ} 02^{\prime} 26.7^{\prime \prime} \mathrm{S}$ 38²1'42.9"W 309m, 25.XI.2014, fr., J.B. Lima et al. 575 (HUNEB).

Endemic to Brazil, Pachira endecaphylla is widely distributed in the states of Espírito Santo and Rio de Janeiro, where it occurs in seasonal forest environments. It has also been recorded in the states Alagoas, 
Malvaceae $s . l$. in the RCE

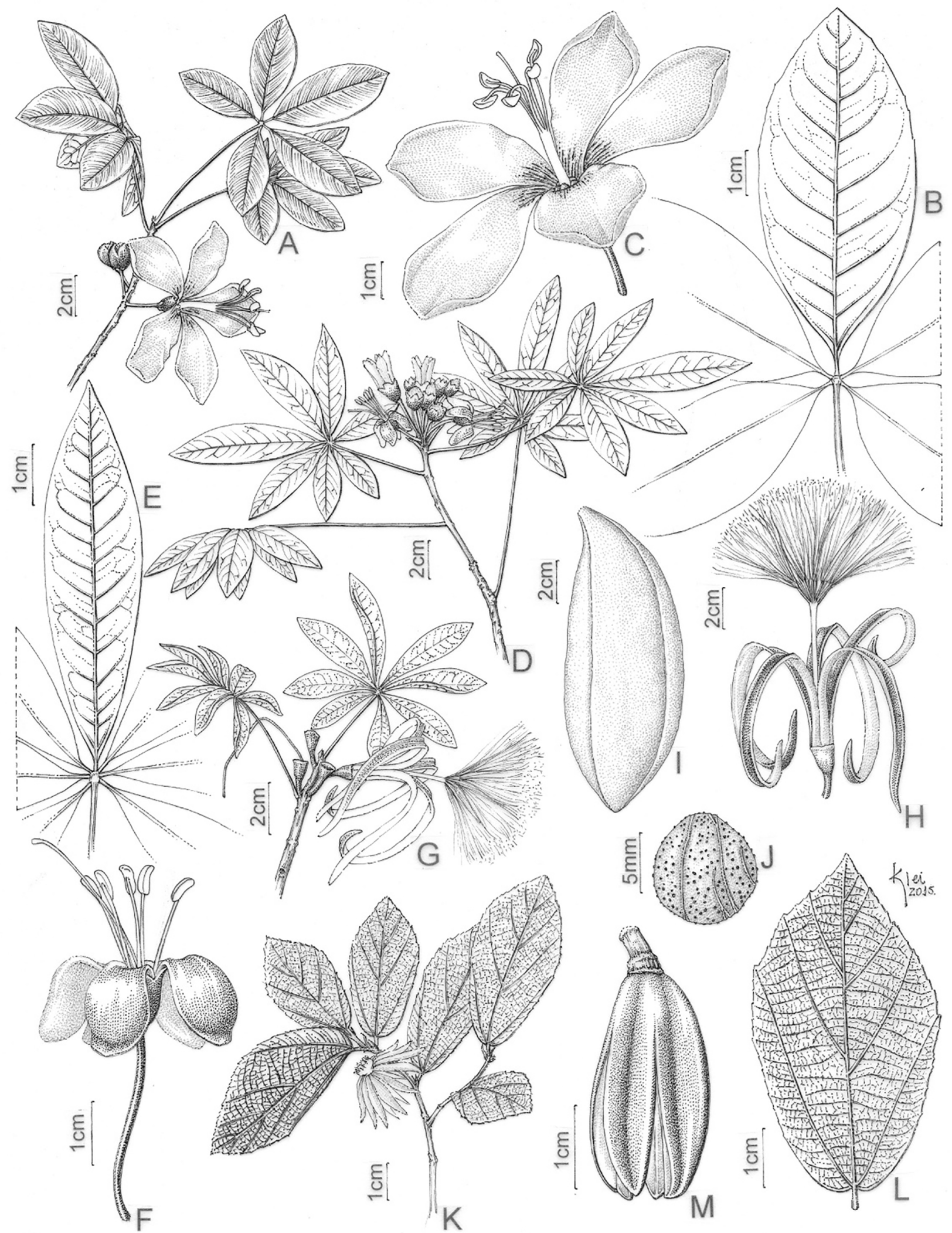

Figure 4. A-C. Ceiba glaziovii. A. flowering branch; B. leaflet; C. flower; D-F. Ceiba pentandra. D. flowering branch; E. leaflet; F. flower. G-J. Pachira endecaphylla. G. flowering branch; H. flower; I. fruit; J. seed. K-M. Luehea candicans. K. flowering branch; L. leaf; M. fruit. A-C from J.B. Lima 107; D-F from J.B. Lima 540; G-J from J.B. Lima 189; K-M from J.B. Lima 509. 
Bahia, Pernambuco, Rio Grande do Norte, Piauí, Sergipe and Tocantins (Carvalho-Sobrinho et al. 2014, Duarte 2015b). In the RCE the species was encountered only in the municipality of Jeremoabo in an area of anthropized Caatinga.

In the study area, $P$. endecaphylla is characterized by having leaves with 7-10 subsessile, oblong to lanceolate leaflets; flowers with a long tube containing a single verticil; completely white stamens; and subglobose seeds with 4 prominent striae and measuring approximately $8 \mathrm{~mm}$ long. It was collected with flowers in March and with fruits in May, June, September and November.

1.6. Pseudobombax parvifolium Carv.-Sobr. \& L.P.Queiroz, Novon 20(1): 17. 2010. Iconography: Carvalho-Sobrinho (2006: 72), CarvalhoSobrinho \& Queiroz (2010: 18). Figure 3F

Tree 5-7 m tall. Trunk not tumescent, inermous, grey, with green longitudinal streaks; branches inerm; brachyblast absent. Stipules deciduous, not observed. Leaves alternate-spirallate, digitate, clustered at the apex of branches; petiole 4-10 cm long, pubescent to glabrescent; leaflets 5-7, subsessile, $2.5-10.4 \times 2.5-5 \mathrm{~cm}$, oblanceolate to elliptic, green, slightly discolorous, chartaceous, base cuneate to atenuate, apex acute-acuminate, margin entire to slightly crenulate, both surfaces glabrescent with trichomes sparse on vein of abaxial surface. Flowers solitary, terminal, clustered at the apex of branches; pedicels 1.4-2.5 $\mathrm{cm}$ long, pubescent to glabrescent with trichomes stellate, ferruginous, sparse; bracteoles 3, deciduous; calyx 1-1.4 cm long, cupuliform to campanulate, dark purple, apex truncate, sometimes slightly 5 apiculate, containing c. 10 glands at the base, externally pubescent, internally sericeous at apical half of; petals $8.5-15 \times 1-1.5 \mathrm{~cm}$, linear-lanceolate, beige to brown, abaxial surface pubescent with trichomes stellate, adaxial surface velutinous being a half with trichomes larger and denser than the other, forming two longitudinal lines; stamens c. 400, white, fused at the base, staminal tube, $1.8-2.2 \mathrm{~cm}$ long, pubescent, originating free fillets, free parts of stamens $8-12 \mathrm{~cm}$ long, anthers monothecate, white, clavate, rimose, basifixed; ovary $8-10 \times 4-5 \mathrm{~mm}$, ovoid, lightly 5 -angulate, subglabrous, 5 locules, numerous ovules per locule; styles $12-16 \mathrm{~cm}$ long, subglabrous, white, stigmas 5 lobed, white. Capsule $8.5-9 \times 4.5-5 \mathrm{~cm}$, elliptic, dehiscence longitudinal, glabrous, woody, cotton-fiber light brown, calyx persistent; seeds $5-6 \times c .4 \mathrm{~mm}$, subreniform, brown with macules inconspicuous slightly darker.

Specimens examined: BRAZIL, BAHIA: Jeremoabo, APA Serra Branca, estrada dos Quelés, 09 $57^{\circ} 45.8^{\prime \prime} \mathrm{S} 38^{\circ} 26^{\prime} 17.4^{\prime \prime} \mathrm{W} 529 \mathrm{~m}$, 05.VI.2012, fr., V.O. Amorim et al. 109 (HUNEB); APA Serra Branca, 0957'27.7"S 3826'17.1”W 493m, 12.XI.2013, fl., M.R.R.M. Mazzotti et al. 02 (HUNEB); Fazenda Serra Branca, 0953'51.5"S 38 40'48.7"W 130m, 30.X.2008, fr., M.V. Romão et al. 386 (HUNEB); Próximo a casa de Antônio Rouxinho, 0957'27.7"S 38²6'15.8”W 492m, 15.V.2014, fl., J.B. Lima et al. 388 (HUNEB); 19.I.2015, fl., J.B. Lima et al. 596 (HUNEB); Depois do povoado Água Branca, próximo a casa de Maria José, 0957'13.1"S 38 41'11.7"W 343m, 30.VII.2014, fl., J.B. Lima et al. 451 (HUNEB); 15.X.2014, fl.; fr., J.B. Lima et al. 542 (HUNEB); Fazenda Serra Branca, ao lado da casa principal, 09 $57^{\prime} 24.5^{\prime \prime} \mathrm{S}$ $38^{\circ} 42^{\prime} 22.4^{\prime \prime} \mathrm{W} 328 \mathrm{~m}, 15 . X .2014$, fr., J.B. Lima et al. 543 (HUNEB); 25.XI.2014, fr., J.B. Lima et al. 577 (HUNEB); Povoado Brejinho, próximo a casa verde $10^{\circ} 02^{\prime} 26.7^{\prime \prime} \mathrm{S} 38^{\circ} 21^{\prime} 42.9^{\prime \prime} \mathrm{W} 309 \mathrm{~m}, 25 . \mathrm{XI} .2014$, fl., J.B. Lima et al. 574 (HUNEB).
Endemic to the Caatinga, it occurs in Northeast Region of Brazil, of the states of Bahia, Ceará, Paraíba, Pernambuco, Piauí, Rio Grande do Norte and Sergipe, in Southeast only of the state of Minas Gerais (Carvalho-Sobrinho \& Queiroz 2010, Duarte 2015c). In the RCE, $P$. parvifolium was collected mainly in the EPASB (Jeremoabo), but also in the municipalities of Paulo Afonso, Tucano and Chorrochó.

Pseudobombax parvifolium can be recognized in the study area by 5-7 foliate leaves; short, pubescent staminal tube with ca. 400 stamens; fruit of c. $5 \mathrm{~cm}$ long; and by subreniform seeds with inconspicuous macules. It was collected with flowers in May, July and October to January and with fruits in October and November.

1.7. Pseudobombax simplicifolium A.Robyns, Bull. Jard. Bot. État Bruxelles 33: 81. 1963. Iconography: Du Bocage \& Sales (2002: 135), Carvalho-Sobrinho (2006: 78). Figure 3G

Tree 6-8 m tall. Trunk not tumescent, inermous, grey, with green longitudinal streaks; branches inermous; brachyblast present. Stipules deciduous, not observed. Leaves alternate-spirallate, clustered at the apex of brachyblast; petiole $0.3-3.4 \mathrm{~cm}$ long, glabrous; leaflets $1(-3)$, sessile, 3.7-8.1 $\times 1.5-4 \mathrm{~cm}$, elliptic to ovate-elliptics, green, discolorous, chartaceous, base obtuse, apex acute, margin entire, both surfaces glabrous. Flowers solitary, terminal, at the apex of brachyblast; pedicels 1.7-2 cm long, glabrous; bracteoles 3 , triangular ca. $2 \mathrm{~mm}$ long; calyx $0.7-1.3 \mathrm{~cm}$ long, campanulate, dark purple, apex truncate, containing 5-6 glands at the base; externally glabrous, internally sericeous at the apical half of; petals $7-15 \times 0.8-1.1 \mathrm{~cm}$, linear-lanceolate, beige to brown, abaxial surface pubescent with trichomes stellate, adaxial surface velutinous with trichomes simple and long, and trichomes stellate thin forming a marginal line c. $2 \mathrm{~mm}$ larg; stamens 240-350, white, fused at the base, staminal tube, $0.7-1.1 \mathrm{~cm}$ long, glabrous, free parts of stamens 5-12 cm long, anthers monothecate, white, clavate, rimose, basifixed; ovary 5-6×3-4 mm, conic, not costate, glabrescent, 5 locules, numerous ovules per locule; styles $12-13.5 \mathrm{~cm}$ long, glabrous, white, stigmas 5 lobed, white. Capsule $11-13 \times 1.8-2.5 \mathrm{~cm}$, oblong, dehiscence longitudinal, glabrous, subwoody, cotton-fiber beige brownish, calyx persistent; seeds $5 \times 3 \mathrm{~mm}$, piriform to subglobose, light brown, without macules.

Specimens examined: BRAZIL, BAHIA: Bendengó, estrada sentido Uauá, BR235/Km204, 0957'08.7"S 39¹6'10.9"W 463m, 18.X.2014, fl., J.B. Lima et al. 562 (HUNEB); Uauá, 4 km depois de Uauá, estrada sentido Monte Santo, 0952'43.4"S 39²9'21.0"W 473m, 18.X.2014, fl.; fr., J.B. Lima et al. 568 (HUNEB); 0952'51.8"S 39²9'24.4"W 473m, 18.X.2014, fl.; fr., J.B. Lima et al. 569 (HUNEB).

Pseudobombax simplicifolium is endemic to the Caatinga, with records in the west regions of the state of Pernambuco, south region of Piauí, Bahia, Sergipe and Minas Gerais (Robyns 1963, Du Bocage \& Sales 2002, Carvalho-Sobrinho 2006, Duarte 2015c). Being an indicator of the Caatinga domain, in the RCE the species was found only in the vicinity of the municipality of Uauá.

The species is recognized by having branches containing brachyblasts; 1(-3) foliate leaves; a short, glabrous staminal tube; fruits up to $2.5 \mathrm{~cm}$ in length; and seeds without macules. It was found in RCE with flowers in August and October and fruits in October. It is noteworthy for its wood and fiber production potential (Sampaio et al. 2005). 


\section{Byttnerioideae Burnett}

Subshrubs to shrubs. Leaves simple, entires, venation palmately. Flowers actinomorphic, bissexual, diclamid, solitary or usually in inflorescence axillary or terminal. Calyx gamosepalous with 5 lobes. Corolla with 5 petals, fused in the base of staminal tube. Stamens 5 , fused at the base, forming a staminal tube, with or without androgynophore, anthers rimose, dorsifixed. Ovary super; one ovule per locule, placentation axile. Fruit capsule.

Consisting of 26 genera and 650 species, Byttnerioideae occurs in the tropics of the New and Old World (Bayer \& Kubitzki 2003). In the $\mathrm{RCE}$ it is represented by three genera and nine species.

2.1. Ayenia hirta A.St.-Hil. \& Naudin, Ann. Sci. Nat., Bot. sér. 2, 18: 34. 1842. Iconography: Cristóbal (1960: 161). Figures 3H; 5H-K

Subshrubs 30-50 cm tall; branches cylindrical, not flexuose, hisutetomentose, trichomes stellate sessile and simple sparse. Stipules linear 1-1.5 mm long, trichomes simple. Leaves alternate-spirallate; petiole 2-5 mm long, trichomes equal to branches; leaf blades $0.7-2.5 \times 0.3-1.1$ $\mathrm{cm}$, ovate to elliptic, green, discolorous, chartaceous, base rounded to subchordate, apex acute, margin serrate, both surfaces tomentose, with trichomes stellate, more dense at the abaxial surface. Inflorescence cymose 3-5-flowers; pedicels 1-2 mm long; bracteoles absent; calyx $2-2.5 \mathrm{~mm}$ long, lobes with apex triangular, externally with trichomes stellate, internally with trichomes glandular; petals rose to purple, claw 3-3.8 mm long, glabrous, connecting the base of the androgynophore, blade 1-1.2 $\times 1-1.2 \mathrm{~mm}$, pilose; androgynophore $1.5-1.8 \mathrm{~mm}$ long, staminal tube, $0.5-0.6 \mathrm{~mm}$ long, free parts of stamens c. $0.2 \mathrm{~mm}$ long; free parts of staminodes c. $0.3 \mathrm{~mm}$ long, anthers 3-thecate; ovary c. $0.5 \times 0,5 \mathrm{~mm}$, globose, papilate, 5 locules, 2 ovules per locule; styles $0.2-0.3 \mathrm{~mm}$ long, stigmas capitate. Capsule 4-5×5-6 mm; subglobose, dehiscence loculicidal, aculeus with trichomes stellate and simple, ferrugineous; seeds $2.5-3 \times 1.8-2 \mathrm{~mm}$, dark brownish to blackened, tuberculate, glabrous.

Specimens examined: BRAZIL, BAHIA: Banzaê, povoado

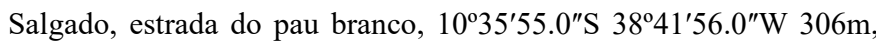
15.I.2014, fr., J.B. Lima et al. 157 (HUNEB); Povoado Serrota, 09²3'19.1"S 38²7'19.4"W 403m, 23.IV.2014, fl.; fr., J.B. Lima et al. 311 (HUNEB); J.V. Santos et al. 292 (HUNEB); L.R. Silva et al. 285 (HUNEB); Paulo Afonso, saindo do Arrastapé em direção a ESEC, 09³4'32.6"S 38 $19^{\prime} 28.5^{\prime \prime} \mathrm{W} 373 \mathrm{~m}, 06 . V .2014$, fl.; fr., J.B. Lima et al. 318 (HUNEB); Estação Ecológica Raso da Catarina, próximo a base nova (3), 09³4'51.5"S 38 29'27.8"W 622m, 22.VII.2014, fl.; fr., J.B. Lima et al. 449 (HUNEB); 03.IX.2014, fl.; fr., J.B. Lima et al. 538 (HUNEB); Jeremoabo, Olho d'água dos negros, $10^{\circ} 01^{\prime} 11.7^{\prime \prime S} 38^{\circ} 22^{\prime} 08.7^{\prime \prime W} 432 \mathrm{~m}, 5 . V I .2014$, fl.; fr., J.B. Lima et al. 408 (HUNEB); Cícero Dantas, Fazenda Pombos, sentido boqueirão, $10^{\circ} 34^{\prime} 37.3^{\prime \prime} \mathrm{S} 38^{\circ} 23^{\prime} 47.4^{\prime \prime} \mathrm{W}$ 403m, 04.VIII.2014, fl.; fr., J.B. Lima et al. 480 (HUNEB); Estrada do Sapé 10 19'28.5"S 38 35'42.8"W 614m, 05.VIII.2014, fl.; fr., J.B. Lima et al. 490 (HUNEB).

Endemic to the Caatinga in the state of Bahia, Northeast Region of Brazil, Ayenia hirta (Cristóbal 1960, Esteves 2015a). Widely distributed in the RCE, the species is common on roadsides.

Ayenia hirta can be recognized by hirsute branches; flowers measuring less than $1 \mathrm{~cm}$; purple petals containing claw that bind to the base of the androgynophore; presence of 3-thecate anthers; and by aculeate fruits with loculicidal dehiscence. It was found with flowers and fruits throughout the year.

2.2. Melochia betonicifolia A.St.-Hil., Fl. Bras. Merid. 1(4): 165. 1825. Iconography: Cristóbal (2006: 109), Gonçalez \& Esteves (2017: 444). Figure $3 \mathrm{I}$

Subshrubs c. $1.30 \mathrm{~m}$ tall; branches cylindrical, not flexuose, tomentose, trichomes stellate sessile. Stipules 3-5 mm long, linear, trichomes simple and stellate. Leaves alternate-spirallate; petiole 5-30 $\mathrm{mm}$ long, trichomes equal to branches; leaf blades $2.7-10.5 \times 1.4-5.4$ $\mathrm{cm}$, ovate, green, discolorous, chartaceous, base rounded to truncate, apex acute, margin crenate, both surfaces pubescent, with trichomes stellate, more dense at the abaxial surface. Inflorescence cymose, umbeliform, oppositifolious terminal; pedicels 4-7 mm long; bracteoles absent; calyx 5-7 mm long, campanulate, green, lobes with apex lanceolate-acuminate, externally with trichomes stellate, internally glabrous; petals flat, 7-8 $\times$ c. $2 \mathrm{~mm}$, spatulate, white with yellow base, glabrous, appendages absent; androgynophore absent; staminal tube c. $1.5 \mathrm{~mm}$ long, free parts of stamens $7-8 \mathrm{~mm}$ long in brevistylous flowers, anthers dithecate; ovary $2-3 \times c .1 \mathrm{~mm}$, elliptic, hirsute at apex, 5 locules, 2 ovules per locule; styles $2-3 \mathrm{~mm}$ long in brevistylous flowers, longistylous flowers not observed, stigmas papilate. Capsule $0.7-1.5 \times 1-2 \mathrm{~cm}$, pyramidal, dehiscence loculicidal, tomentose, trichomes stellate, aculeus absent; seeds $1.5 \times 0.5 \mathrm{~mm}$, ellipsoid, light brown, glabrous.

Specimens examined: BRAZIL, BAHIA: Cícero Dantas, boqueirão, em frente a casa de Jorge, $10^{\circ} 33^{\prime} 21.1^{\prime \prime S} 38^{\circ} 24^{\prime} 29^{\prime \prime} \mathrm{W} 406 \mathrm{~m}$, 04.VIII.2014, fl.; fr., J.B. Lima et al. 476 (HUNEB). Euclides da Cunha, estrada em direção ao pai João André, Bela Vista, 10³0'35.3"S 3901'11.2"W 253m, 18.III.2015, fl.; fr., J.B. Lima et al. 610 (HUNEB).

Endemic to Brazil, Melochia betonicifolia occurs in the Northeast (Bahia, Ceará, Pernambuco) and Southeast (Minas Gerais, Rio de Janeiro) regions, in Caatinga, Cerrado and Atlantic Forest (Cristóbal 2006, Gonçalez 2013, Gonçalez 2018). It was few found in the RCE, where the species was found in areas of anthropized Caatinga.

Melochia betonicifolia differs from its congeners by having a white corolla with a yellow base measuring less than $1 \mathrm{~cm}$ long, and associated with the presence of pyramidal fruits. It was collected with flowers and fruits in March and August.

2.3. Melochia illicioides K.Schum., Fl. Bras. (Martius) 12(3): 31. 1886. Figures 3J; 5L-N

Subshrubs c. $1.8 \mathrm{~m}$ tall; branches cylindrical, not flexuose, tomentose, trichomes stellate sessile. Stipules c. $2 \mathrm{~mm}$ long, linear, trichomes simple and stellate. Leaves alternate-spirallate; petiole 5-17 $\mathrm{mm}$ long, trichomes equal to branches; leaf blades $2.5-7 \times 1.5-4 \mathrm{~cm}$, ovate to elliptic, green, discolorous, membranaceous, base rouded to subchordate, apex acute, margin crenate, both surfaces pubescent, trichomes stellate, more dense at the abaxial surface. Inflorescence cymose, umbeliform, oppositifolious terminal; pedicels 6-8 mm long; bracteoles absent; calyx 5-8 mm long, campanulate, green-vinaceous, lobes with apex lanceolate-acuminate, externally with trichomes stellate, internally trichomes only at apex; petals flat, $12-15 \times$ c. $5 \mathrm{~mm}$, 


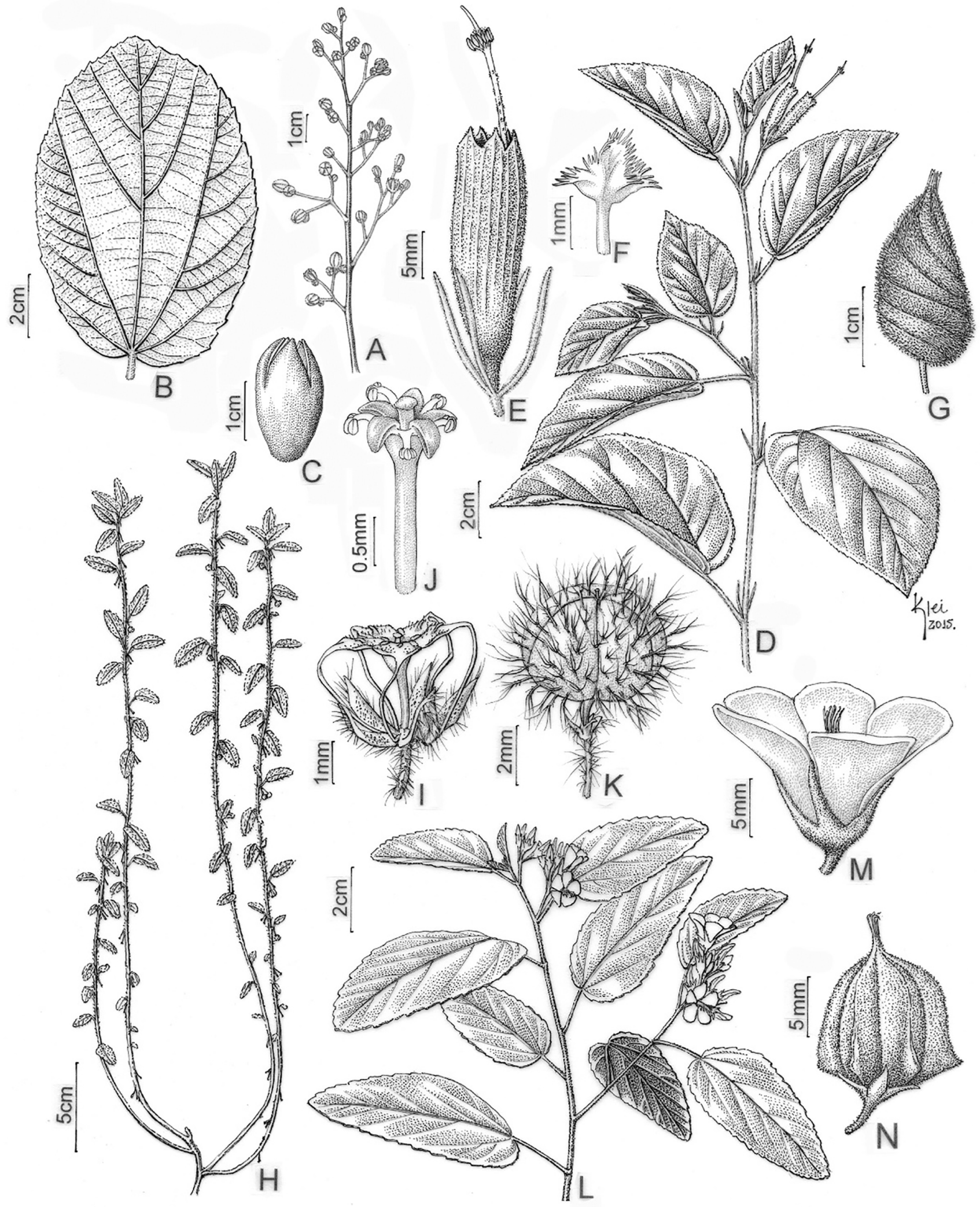

Figure 5. A-C. Luehea paniculata. A. inflorescence; B. leaf; C. fruit; D-G. Helicteres eichleri. D. flowering branch; E. flower and linear profiles; F. petal; G. fruit. H-K. Ayenia hirta. H. flowering branch; I. flower; J. androgynophore; K. fruit. L-N. Melochia illicioides. L. flowering branch; M. flower; N. fruit. A-C. from J.B. Lima 492; D-G from J.B. Lima 578; H-K from J.B. Lima 490; L-N from R.R. Varjão 30. 
obovate to spatulate, white with yellow base, glabrous, appendages absent; androgynophore absent, staminal tube, c. $1.5 \mathrm{~mm}$ long, free parts of stamens 6-10 mm long in brevistylous flowers, 4-6.5 mm long in longistylous flowers, anthers dithecate, yellow; ovary c. $3 \times 2 \mathrm{~mm}$, ovate-elliptic, hirsute at apex, 5-6 locules, 2 ovules per locule; styles 3-5 $\mathrm{mm}$ long in brevistylous flowers, 6-9 $\mathrm{mm}$ long in longistylous flowers, trichomes stellate, stigmas papilate. Capsule $1-1.7 \times 0.7-1.8$ $\mathrm{cm}$, pyramidal, conic-globose, dehiscence loculicidal, tomentose, trichomes stellate, aculeus absent; seeds $1.5-2 \times 0.5-1 \mathrm{~mm}$, ellipsoid, ligth brown, glabrescent.

Specimens examined: BRAZIL, BAHIA: Jeremoabo, APA Serra Branca, estrada da ESEC aos Quelés, 0956'56.6"S 38²7'04"W 586m, 27.I.2011, fl.; fr, R.R. Varjão et al. 30 (HUNEB); Estrada secundária que dá acesso a ESEC, 0956'36.6"S 38²7'27.2"W 558m, 11.VII.2012, fl.; fr, J.B. Lima et al. 43 (HUNEB); 09 56'37.3"S 38²7'05.3"W 510m, 20.X.2013, fl.; fr, J.B. Lima et al. 129, 131 (HUNEB).

Melochia illicioides is known only from the city of Honda, in Colombia, and the state of Bahia, in Brazil, where it grows among Atlantic Forest and Cerrado vegetation (Goldberg 1967, Gonçalez 2018). It is treated here as a new occurrence for the Caatinga. In the RCE the species was found only in the EPASB.

In the RCE, M. illicioides can be recognized by its white corolla of $12-15 \mathrm{~mm}$ in length and by its pyramidal, conic-globose, fruit. It flowers and fruits throughout the year.

2.4. Melochia tomentosa L., Syst. Nat., ed. 10. 2: 1140. 1759. Iconography: Rondón \& Campos (2006: 149), Rondón (2007: 134, 2009: 54). Figure $3 \mathrm{~K}$

Subshrubs 1-1.30 m tall; branches cylindrical, not flexuose, pubescent, trichomes stellate sessile. Stipules 2-3 mm long, linear, trichomes equal to branches. Leaves alternate-spirallate; petiole $1.5-5$ $\mathrm{mm}$ long, tomentose; leaf blades $0.8-3.5 \times 0.5-2.5 \mathrm{~cm}$, ovate to elliptic, green, discolorous, chartaceous, base obtuse to subchordate, apex retuse, margin crenate-serrate, both surfaces tomentose, trichomes stellate. Inflorescence cymose, umbeliform, axillary and terminal; pedicels 5-7 mm long; bracteoles absent; calyx 5-7 mm long, campanulate, green-vinaceous, lobes with apex acuminate, externally with trichomes stellate, internally trichomes only at the apex; petals flat, $8-10 \times 5-7$ $\mathrm{mm}$, obovate, lilac with yellow base, glabrous, appendages absent; androgynophore absent; staminal tube c. $1.5 \mathrm{~mm}$ long, free parts of stamens 6-12 mm long in brevistylous flowers, 5-7 mm long in longistylous flowers, anthers dithecate; ovary c. $2 \times 1 \mathrm{~mm}$, ellipsoid, tomentose at the apex, 5 locules, 2 ovules per locule; styles $3-5.2 \mathrm{~mm}$ long in brevistylous flowers, 6-8 $\mathrm{mm}$ long in longistylous flowers, trichomes stellate in both forms, stigmas papilate. Capsule $0.8-1 \times 0.8-1$ $\mathrm{cm}$, pyramidal, dehiscence loculicidal, tomentose, trichomes stellate, aculeus absent; seeds c. $2.1 \times 1.5 \mathrm{~mm}$, ellipsoid, dark brown, glabrous

Specimens examined: BRAZIL, BAHIA: Jeremoabo, APA Serra Branca, próximo ao barreiro, 09 $52^{\circ} 46.5^{\prime \prime} \mathrm{S} 38^{\circ} 40^{\prime} 00.9^{\prime \prime} \mathrm{W} 472 \mathrm{~m}$, 24.I.2013, fl., V.O. Amorim et al. 209 (HUNEB); Fazenda Serra Branca, tanque de dentro, 09 $51^{\prime} 55.6^{\prime \prime} \mathrm{S} 38^{\circ} 38^{\prime} 45.2^{\prime \prime} \mathrm{W} 156 \mathrm{~m}$, 30.X.2008, fl., M.V. Romão et al. 390 (HUNEB); Caminho da Judite, próximo a serra do navio, 0951'55.5"S 38³8'45"W 469m, 03.XI.2011, fl.; fr., J.B. Lima et al. 02, 04 (HUNEB); Estrada em direção a serra do navio, após o dedo de Deus, 0952'43.4"S 38³9'14.5"W 463m, 11.II.2014, fl.; fr., J.B.
Lima et al. 188 (HUNEB); Roça velha, perto do currau, 0956'45.1"S 38 42'12.6"W 335m, 30.VII.2014, fl.; fr., J.B. Lima et al. 452 (HUNEB); Canudos, Parque Estadual de Canudos, próximo ao açude Cócorobo, 0955'03.6"S 3906'19.6"W 376m, 20.IV.2008, fl., C.L.S.B. Correia et al. 12 (HUNEB); Alto do Mário, 0955'07.6"S 3906'36.6"W 388m, 11.X.2008, fl., C.L.S.B. Correia et al. 49 (HUNEB); Alto da favela, 0954'59.9"S 39007'01.6"W 401m, 22.III.2008, fl.; fr., M.V. Romão et al. 27 (HUNEB); 10.V.2008, fl.; fr., M.V. Romão et al.

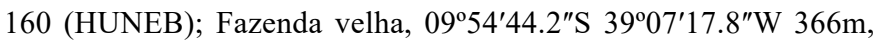
21.IX.2008, fl.; fr., M.V. Romão et al. 344 (HUNEB); Vale da morte, 09 $55^{\prime} 11^{\prime \prime} \mathrm{S} 39^{\circ} 07^{\prime} 01.1^{\prime \prime} \mathrm{W} 376 \mathrm{~m}, 15 . X .2014$, fl.; fr., J.B. Lima et al. 544 (HUNEB); Estação Biológica de Canudos, 0956'41.1"S 3900'55.7"W 443m, 27.III.2014, fl.; fr., J.B. Lima et al. 256 (HUNEB); Paulo Afonso, Estação Ecológica Raso da Catarina, Base velha (petrobras), 0943'52.6"S 38 40'57.1"W 601m, 16.IV.2014, fl.; fr., J.B. Lima et al. 296, 299 (HUNEB); 02.IX.2014, fl.; fr., J.B. Lima et al. 525 (HUNEB); Povoado Arrastapé, 09³0'49.2"S 38¹6'55.3"W 300m, 20.III.2014, fl.; fr., J.B. Lima et al. 216 (HUNEB); Povoado Barrinha, 09³5'11.2"S $38^{\circ} 19^{\prime} 32.2^{\prime \prime} \mathrm{W} 404 \mathrm{~m}, 6 . V .2014$, fl.; fr., J.B. Lima et al. 322 (HUNEB); Macururé, saída em direção a Chorrochó, 0909'02"S 3903'31"W 361m, 2.VI.2014, fl.; fr., J.B. Lima et al. 396 (HUNEB).

It is distributed in the Americas, including Florida, Mexico, Honduras, Nicaragua, Bahamas, Cuba, Haití, Dominican Republic, Jamaica, Curaçao, Puerto Rico, Trinidad, Colombia, Venezuela and Brazil (Rondón 2007, 2009). In Brazil, Melochia tomentosa is found in the Northeast (Alagoas, Bahia, Ceará, Paraíba, Pernambuco, Piauí) and Central-West (Mato Grosso do Sul, Mato Grosso) regions, in a variety of environments such as Caatinga, Cerrado and Atlantic Forest (Gonçalez 2018). The species is widely distributed in the RCE, both in preserved and anthropized areas.

The species can be recognized by its lilac-colored corolla with a yellow base and its axillary umbelliform inflorescence. It was found with flowers and fruits in all months of the year. It possesses medicinal, apicultural and forage potential (Rondón 2009, Sampaio et al. 2005).

2.5. Waltheria albicans Turcz., Bull. Soc. Imp. Naturalistes Moscou 31(1): 214. 1858. Iconography: Cristóbal (2006: 112), Rondón (2008: 14). Figures $3 \mathrm{~L} ; 6 \mathrm{~A}-\mathrm{E}$

Subshrubs 70-80 cm tall; branches cylindrical, not flexuose, tomentose, trichomes glandular and stellate sessile. Stipules $3-5 \mathrm{~mm}$ long, narrow-triangular, trichomes equal to branches. Leaves alternatespirallate; petiole 5-22 mm long, tomentose; leaf blades $2.1-6 \times 1.2-$ $4.9 \mathrm{~cm}$, ovate to orbicular, green slightly canescent, discolorous, chartaceous, base obtuse to subchordate, apex rouded, margin dentate to serrate, both surfaces tomentose, trichomes stellate more dense on abaxial surface. Inflorescence cymose in glomerule, axillary and terminal; pedicels 1-2 mm long; bracteoles 4, 5-6 mm long., linearlanceolate, green, trichomes simple; calyx $6 \mathrm{~mm}$ long, campanulate, green, lobes with apex acuminate, externally sericeous, with trichomes simple, internally with trichomes only at the apex; petals flat, $8-10 \times 3-5$ $\mathrm{mm}$, obdeltoid, yellow, trichomes simple internally, appendages absent; androgynophore absent; staminal tube c. $1 \mathrm{~mm}$ long, free portion of stamens c. $5 \mathrm{~mm}$ long, in brevistylous flowers, anthers dithecate; ovary c. $1 \times 0.5 \mathrm{~mm}$, ovoid to elipsoid, sericeous, 1 locule, 1 ovule per locule; styles c. $1 \mathrm{~mm}$ long in brevistylous flowers, trichomes simple sparse, 


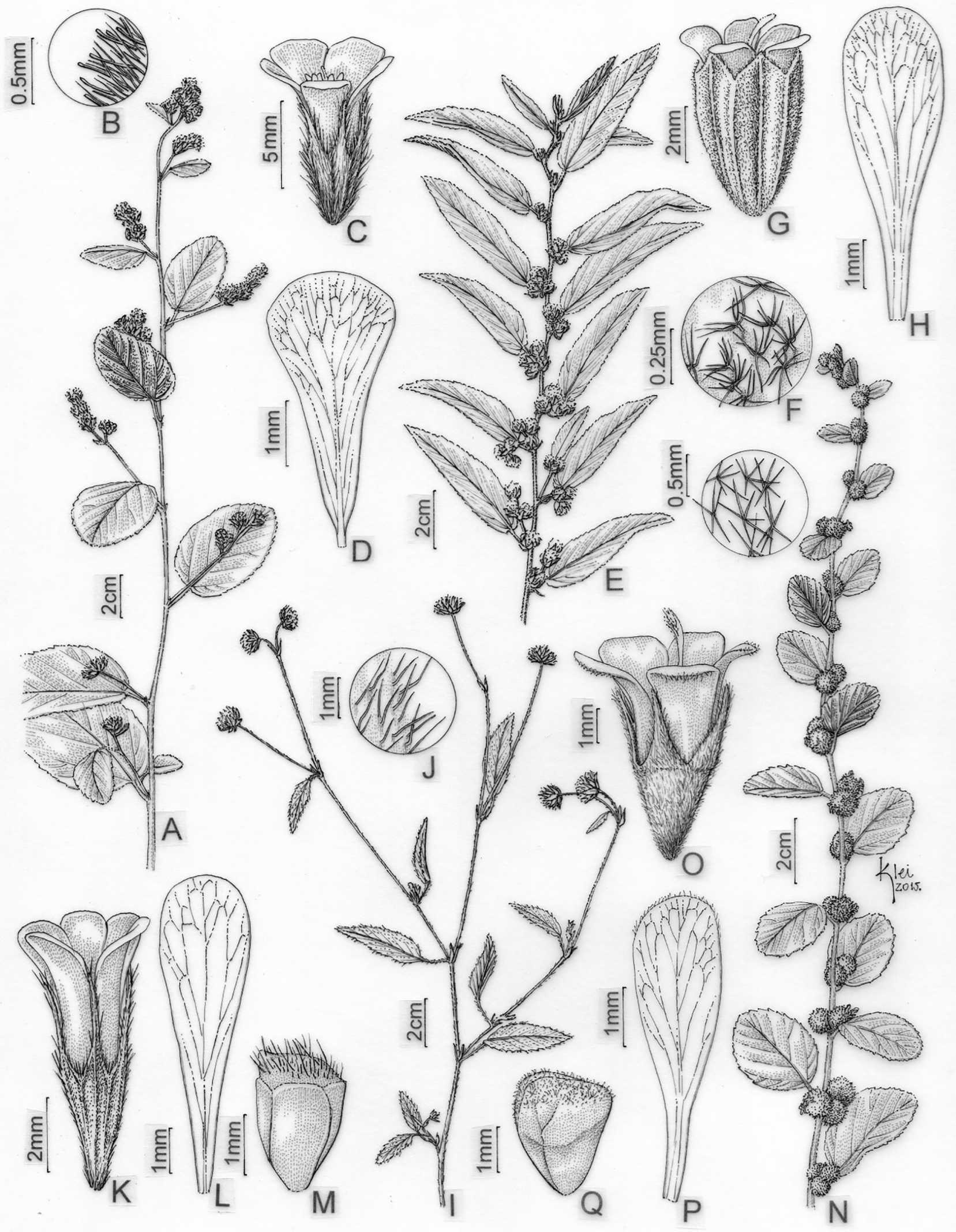

Figure 6. A-D. Waltheria albicans. A. flowering branch; B. detail of branch indumentum; C. flower; D. petal; E-H. Waltheria brachypetala. E. flowering branch; F. detail of branch indumentum; G. flower; H. petal; I-M. Waltheria operculata. I. flowering branch; J. detail of branch indumentum; K. flower; L. petal; M. fruit; N-Q. Waltheria rotundifolia. N. flowering branch and detail of branch indumentum; O. flower; P. petal; Q. fruit. A-D from J.B. Lima 392; E-H from J.B. Lima 371; I-M from J.B. Lima 447; N-Q from J.B. Lima 397. 
form longistylous not observed, stigmas ciliated. Capsule c. $4 \times 2 \mathrm{~mm}$, obovate, dehiscence loculicidal, trichomes simple, aculeus absent; seeds c. $3 \times 2 \mathrm{~mm}$, obovoid, brownish, glabrous.

Specimens examined: BRAZIL, BAHIA: Macururé, povoado Salgado do melão, próximo ao posto de saúde, $09^{\circ} 17^{\prime} 51.7^{\prime \prime} \mathrm{S}$ $38^{\circ} 41^{\prime 2} 24.8^{\prime \prime} \mathrm{W} 422 \mathrm{~m}, 02 . V I .2014$, fl.; fr., J.B. Lima et al. 392 (HUNEB); Jeremoabo, APA Serra Branca, estrada principal em direção a ESEC, 0957'12.1"S 38 26'33.7"W 513m, 19.XII.2013, fl.; fr., J.B. Lima et al. 127 (HUNEB); Baixa da forra, perto da roça do Sr. Antônio Roxinho, $09^{\circ} 57^{\prime} 16.1^{\prime \prime} \mathrm{S} 38^{\circ} 26^{\prime 2} 23.2^{\prime \prime} \mathrm{W} 505 \mathrm{~m}$, 19.XII.2013, fl.; fr., T.D.C. Batista et al. 31 (HUNEB).

Waltheria albicans is distributed in Argentina, Brazil, Bolivia, Colombia, Guiana, Mexico, Paraguay and Venezuela (Cristóbal 1998, Rondón 2008). In Brazil it is found in the Amazon Rainforest, Caatinga and Cerrado. In the Northeast Region it is distributed among the states of Bahia, Ceará, Maranhão, Pernambuco and Piauí (Esteves 2015b). It was few found in the RCE, where the species was found in an open field.

In the RCE, the species can be recognized by an indumentum with two branches with glandular trichomes and obdeltoid petals reaching 10 $\mathrm{mm}$ in length. It was found with flowers and fruits throughout the year.

2.6. Waltheria brachypetala Turcz., Bull. Soc. Imp. Naturalistes Moscou 31(1): 215. 1858. Figures 3M; 6F-J

Popular name: malva-preta.

Shrubs 1.5-2 m tall; branches cylindrical, flexuose, tomentose, trichomes stellate stipitated. Stipules c. $6 \mathrm{~mm}$ long, linear, trichomes equal to branches. Leaves alternate-spirallate; petiole 4-7 $\mathrm{mm}$ long, tomentose; leaf blades $3.5-7 \times 1.2-2.5 \mathrm{~cm}$, lanceolate slightly falciform, green canescent, concolor, chartaceous, base obtuse to rounded, apex acuminate, margin dentate, both surfaces tomentose, trichomes stellate. Inflorescence cymose in glomerule, axillary, bracts c. $6 \mathrm{~mm}$ long, filiform, tomentose; pedicels $1-2 \mathrm{~mm}$ long; bracteoles 3 , c. $5.5 \times 3.5$ $\mathrm{mm}$, elliptic, sericeous; calyx c. $5 \mathrm{~mm}$ long, campanulate, green, lobes with apex acute, externally with trichomes stellate, internally glabrous; petals flat, c. $6 \times 4 \mathrm{~mm}$, spatulate, yellow, glabrous; androgynophore absent, staminal tube c. 1.8-2 mm long in brevistylous flowers, 2-3.5 $\mathrm{mm}$ long in longistylous flowers, free portion of stamens c. $0.5 \mathrm{~mm}$, anthers dithecate, yellow; ovary c. $0.8 \times 3.5 \mathrm{~mm}$, ellipsoid, velutinous, 1 locule, 1 ovule per locule; styles $1-1.8 \mathrm{~mm}$ long in brevistylous flowers, 4-5.2 mm long in longistylous flowers, stigmas plumose. Capsule c. $3 \times 2 \mathrm{~mm}$, ellipsoid, dehiscence apical, trichomes stellate, aculeus absent; seeds $2-2.5 \times 1.3-1.7 \mathrm{~mm}$, obovoid, brownish, glabrous.

Specimens examined: BRAZIL, BAHIA: Jeremoabo, APA Serra Branca, estrada saíndo dos Quelés sentido ESEC, 0956'45.7"S $38^{\circ} 27^{\prime} 30.1^{\prime \prime} \mathrm{W} 607 \mathrm{~m}, 29 . V I I .2009$, fl., T.M. Silva et al. 145 (HUNEB); Caminho perto de Quelés, 0954'16.8"S 38²9'33.5"W 605m, 08.IX.2009, fl.; fr., M.V. Romão et al. 526 (HUNEB); Estrada secundária sentido ESEC, 0956'36.6"S 38²7'27.2"W 558m, 11.VII.2012, fl.; fr., J.B. Lima et al. 42 (HUNEB); Paulo Afonso, Estação Ecológica Raso da Catarina, trilha sentido mata da Pororoca, 0944'37.4"S 38 29'28.8"W 648m, 24.IX.2013, fl., J.B. Lima et al. 103 (HUNEB); Caminho para a base velha da petrobrás, $09^{\circ} 39^{\prime} 02.4^{\prime \prime} \mathrm{S} 38^{\circ} 29^{\prime} 38.1^{\prime \prime} \mathrm{W}$ 621m, 16.IV.2014, fl.; fr., J.B. Lima et al. 286 (HUNEB); Base velha (petrobras), 0943'52.6"S 38 40'57.1"W 601m, 10.VI.2014, fl.; fr., J.B. Lima et al. 424 (HUNEB); 02.IX.2014, fl.; fr., J.B. Lima et al. 530 (HUNEB); Trilha sentido sul da estação, ca. de $10 \mathrm{~km}$ da mata da
Pororoca, 0952'19.2"S 38²9'31.4"W 629m, 08.IX.2011, fl., C.L.S.B. Correia et al. 562 (HUNEB); Próximo a casa 2 do ICMBio, trilha da baixa da cascavel, 0944'176"S 3840'967"W 593m, 26.IX.2011, fl., C.L.S.B. Correia et al. 576 (HUNEB); Canudos, Estação Biológica de Canudos, trilha para o saco das araras, 0958'26.6"S 38 59'42.1"W 566m, 26.III.2014, fl., J.B. Lima et al. 222 (HUNEB); Baixada depois da base 2, caminho para base $1,09^{\circ} 56^{\prime} 46.4^{\prime \prime} \mathrm{S} 39^{\circ} 00^{\prime} 42.7^{\prime \prime} \mathrm{W} 433 \mathrm{~m}$, 26.III.2014, fl.; fr., J.B. Lima et al. 224 (HUNEB); Caminho da lagoa dos Manezão, 0956'47.7"S 3900'43.2"W 421m, 13.V.2014, fl.; fr., J.B. Lima et al. 371 (HUNEB); Saco do gavião, 0957'16.4"S 3900'13.6"W 422m, 14.V.2014, fl.; fr., J.B. Lima et al. 378 (HUNEB); Baixada depois da base 2, trilha em direção aos sacos das araras, 0956'46.3"S 3900'33.4"W 425m, 16.X.2014, fl.; fr., J.B. Lima et al. 551 (HUNEB); Quinjingue, povoado Tanque do rumo, 10 $0^{\circ} 43^{\prime} 52.2^{\prime \prime} \mathrm{S} 38^{\circ} 54^{\prime} 13.2^{\prime \prime} \mathrm{W}$ 343m, 06.VIII.2014, fl., J.B. Lima et al. 501 (HUNEB).

Endemic to Caatinga of the Northeastern Brazil, Waltheria brachypetala is recorded from the states of Bahia, Ceará, Pernambuco and Piauí. Is considered an indicator of this environment (Amorim et al. 2009, Esteves 2015b). It is widely distributed in the RCE, and can be found forming dense populations in conservation units.

Waltheria brachypetala is recognized by flexuous branches with stellate stipitate trichomes; lanceolate, slightly falciform leaves; and sericeous bracts and calyces. It flowers and fruits throughout the year.

2.7. Waltheria indica L., Sp. Pl. 2: 673. 1753. Iconography: Cristóbal (2006: 112), Rondón \& Campos (2006: 150), Cruz (2007: 69), Rondón (2008: 24). Figure 3N

Subshrubs $0.5-1.30 \mathrm{~m}$ tall; branches cylindrical, not flexuose, pubescent, trichomes simple and stellate sessile. Stipules 3-5 mm long, lanceolate, trichomes equal to branches. Leaves alternate-spirallate; petiole $0.6-2 \mathrm{~cm}$ long, pubescent; leaf blades $1.5-6.5 \times 1-3 \mathrm{~cm}$, ovateelliptic, green not canescent, discolorous, chartaceous, base obtuse, apex acute, margin serrate, both surfaces pubescent, trichomes simple and stellate. Inflorescence cymose in glomerule dense, axillary; pedicels 1-2 $\mathrm{mm}$ long; bracteoles 3-4, c. 4-6 mm long, lanceolate, green, trichomes simple; calyx 4-5 mm long, campanulate, light green, lobes with apex acuminate, externally pubescent, with trichomes simple, internally with trichomes only to apex; petals flat, 4-6×0.5-1 mm, spatulate, yellow, trichomes simple at apex; staminal tube c. $2 \mathrm{~mm}$ long, free portion of stamens c. $0.5 \mathrm{~mm}$ long, anthers dithecate, yellow; ovary c. $1 \times 0.5 \mathrm{~mm}$, ovoid to elipsoid, sericeous, 1 locule, 2 ovules per locule; styles c. 1.5 $\mathrm{mm}$ long, with trichomes stellate, stigmas plumose. Capsule c. $3 \times 2$ $\mathrm{mm}$, obovate, indehiscent, trichomes simple at apical portion, aculeus absent; seeds c. $2.5 \times 1.6 \mathrm{~mm}$, obovoid, brownish, glabrous.

Specimens examined: BRAZIL, BAHIA: Jeremoabo, Fazenda Serra Branca, a 9,5 km de distância da base da APA, baixão do araçá, 0953'08.6"S 38 38'02.3"W 595m, 08.V.2008, fl.; fr., M.V. Romão et al. 138 (HUNEB); Base do ICMBio, 0955'17.3"S 38 42'06"W 334m, 20.XII.2011, fl.; fr., J.B. Lima et al. 20 (HUNEB); Jeremoabo, $10^{\circ} 15^{\prime} \mathrm{S}$ 38³' W, 29.X.1981, fl.; fr., R.P. Orlandi 570 (HRB, RB); Canudos, Estação biológica de Canudos, proximidades da base 02, 0956'41.1"S 3900'55.7"W 443m, 26.III.2014, fl.; fr., J.B. Lima et al. 227 (HUNEB); Lagoa dos Manezão, 0956'58.2"S 3900'55.1"W 435m, 17.X.2014, fl.; fr., J.B. Lima et al. 561 (HUNEB); Parque Estadual de Canudos, Vale da morte, $09^{\circ} 55^{\prime} 11^{\prime \prime} \mathrm{S} 39^{\circ} 07^{\prime} 01.1^{\prime \prime} \mathrm{W} 376 \mathrm{~m}, 15 . X .2014$, fl.; fr., J.B. Lima et al. 549 (HUNEB); Paulo Afonso, Estação Ecológica Raso da 
Catarina, Base velha da Petrobrás, 0943'59.7"S 3840'56.3"W 598m, 19.III.2014, fl.; fr., J.B. Lima et al. 210, 213 (HUNEB); Estrada sentido

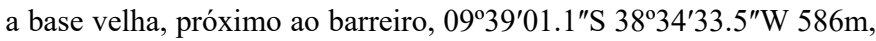
16.IV.2014, fl.; fr., J.B. Lima et al. 293 (HUNEB); Proximidades da base velha, 09²3'52.6"S 38 40'57.1"W 601m, 10.VI.2014, fl.; fr., J.B. Lima et al. 423 (HUNEB); 02.IX.2014, fl.; fr., J.B. Lima et al. 526 (HUNEB); Povoado barrinha, 09³5'11.2"S 38¹9'32.2"W 404m, 6.V.2014, fl.; fr., J.B. Lima et al. 320, 323 (HUNEB); Cícero Dantas, Fazenda Pombos, sentido boqueirão, 10³4'37.3"S 38 23'47.4"W 403m, 04.VIII.2014, fl.; fr., J.B. Lima et al. 482 (HUNEB); Estrada do sapé, $10^{\circ} 19^{\prime} 32.5^{\prime \prime} \mathrm{S} 38^{\circ} 35^{\prime} 26.2^{\prime \prime} \mathrm{W} 622 \mathrm{~m}$, 05.VIII.2014, fl.; fr., J.B. Lima et al. 495 (HUNEB); Cícero Dantas, 10³6'S 39²3'W, 18.VIII.2003, fl.; fr., M.L. Guedes et al. 10559 (ALCB); Euclides da Cunha, Fazenda Binjé, do Sr. Alan, $10^{\circ} 34^{\prime} 07.4^{\prime \prime}$ S 3901'01.8"W 462m, 07.VIII.2014, fl.; fr., J.B. Lima et al. 504 (HUNEB); Banzaê, povoado Salgado, estrada do pau branco, $10^{\circ} 35^{\prime} 55^{\prime \prime} \mathrm{S} 38^{\circ} 41^{\prime} 56^{\prime \prime} \mathrm{W} 306 \mathrm{~m}$, 15.I.2014, fl., J.B. Lima et al. 158 (HUNEB).

The only species of the genus with a Pantropical distribution, Waltheria indica is present in all of the states and phytogeographic dominions of Brazil (Saunders 1995, Esteves 2015b). It is widely distributed in the ecoregion, and is a common species of anthropized areas.

Waltheria indica is recognized by oval-elliptical discolorous leaves and dense inflorescences. According to Cruz (2007), this species exhibits great morphological variability, although it has homostylous flowers, which is a rare character for the genus. It flowers and fruits throughout the year. It possesses medicinal and apicultural potential (Lorenzi \& Matos 2008, Sampaio et al. 2005).

2.8. Waltheria operculata Rose, Contr. U.S. Natl. Herb. 5: 183. 1899. Iconography: (Rondón 2008: 12). Figures 3O; 6K-O

Subshrubs prostate c. $50 \mathrm{~cm}$ tall; branches cylindrical, not flexuose, hirsute, trichomes simple. Stipules 7-11 $\times 3-5 \mathrm{~mm}$, lanceolate, trichomes equal to branches. Leaves alternate-spirallate; petiole $0.5-1.5 \mathrm{~cm}$ long, pilose; leaf blades $1.8-5.2 \times 0.7-2 \mathrm{~cm}$, elliptic to lanceolate, green, discolorous, membranaceous, base cuneate, apex atenuate, margin serrate, both surfaces pubescent, trichomes simple. Inflorescence cymose in glomerule scorpioid, terminal; pedicels 1-2 $\mathrm{mm}$ long; bracteoles 2-3, 5-6 mm long, elliptic, green not canescent, with trichomes simple; calyx $5 \mathrm{~mm}$ long, campanulate, green with apex brownish, lobes with apex acuminate, externally sericeous, with trichomes simple, internally with trichomes only at the apex; petals flat, c. $7 \times 2 \mathrm{~mm}$, spatulate, yellow, glabrous; staminal tube c. $2 \mathrm{~mm}$ long, free portion of stamens c. $0.2 \mathrm{~mm}$ long in longistylous flowers, anthers dithecate, yellow; ovary c. $1 \times 0.5 \mathrm{~mm}$, obovoid, glabrous with operculum sericeous, 1 locule, 1 ovules per locule; styles $0.8-1 \mathrm{~mm}$ long in longistylous flowers, brevistylous flowers not observed, stigmas c. $2 \mathrm{~mm}$ long, ciliated. Capsule c. $3 \times 1-1.5 \mathrm{~mm}$, obovoid, dehiscence apical opercular, trichomes simple at the operculum, aculeus absent; seeds c. $2 \times 1-1.5 \mathrm{~mm}$, obovoid, dark brownish, verrucose, glabrous.

Specimens examined: BRAZIL, BAHIA: Paulo Afonso, povoado Arrastapé, 09³3'07.1"S 38014'53.2"W 269m, 06.V.2014, fl.; fr., J.B. Lima et al. 315 (HUNEB); Entre os povoados Barrinha e Santo Antônio, 09³6'40"S 38²0'16"W 370m, 06.V.2014, fl.; fr., J.B. Lima et al. 328 (HUNEB); Estação Ecológica Raso da Catarina, próximo a base nova
(3), 09³4'51.5"S 38²9'27.8"W 622m, 22.VII.2014, fl.; fr., J.B. Lima et al. 447 (HUNEB); Macururé, saída da cidade em direção a Chorrochó, $09^{\circ} 09^{\prime} 02^{\prime \prime S} 38^{\circ} 03^{\prime} 31^{\prime \prime} \mathrm{W} 361 \mathrm{~m}, 02$. VI.2014, fl.; fr., J.B. Lima et al. 393 (HUNEB); Rodelas, Lote de Natan, perímetro irrigado 4.5, 08 51'16.7"S $38^{\circ} 44^{\prime} 49^{\prime \prime} \mathrm{W} 330 \mathrm{~m}, 03$. VI.2014, fl.; fr., J.B. Lima et al. 405 (HUNEB).

The species is distributed in Bolivia, Colombia, Honduras, Mexico, Paraguay, Venezuela and Brazil (Rondón 2008). In Brazil was recorded in the Northeast Region (Bahia, Paraíba, Pernambuco, Rio Grande do Norte), Central-West (Goiás, Mato Grosso) and Southeast (Minas Gerais, Rio de Janeiro), where it occurs in Caatinga, Cerrado, Atlantic Forest and Swamp (Esteves 2015b). In the RCE, the species was collected in anthropized areas.

Waltheria operculata is recognized in the RCE by its prostrate subshrub habit; an indumentum consisting of solely simple trichomes; and fruits with opercular dehiscence. It flowers and fruits throughout the year.

2.9. Waltheria rotundifolia Schrank, Syll. Pl. Nov. 2: 65. 1828. Figures 3P; 6P-T

Subshrubs 50-70 cm tall; branches cylindrical, not flexuose, tomentose, canescent, trichomes stellate sessile. Stipules 5-7 mm long, linear-lanceolate, trichomes equal to branches. Leaves alternatespirallate; petiole $0.5-1 \mathrm{~cm}$ long, tomentose; leaf blades $1.5-3.2 \times 1.5-3$ $\mathrm{cm}$, orbicular, green canescent, concolorous, chartaceous, base obtuse to truncate, apex rounded, margin dentate to serrate, both surfaces velutinous, with trichomes stellate more dense on abaxial surface. Inflorescence cymose in glomerule, axillary and terminal; pedicels 1-2 $\mathrm{mm}$ long; bracteoles 2-3, 4-6 mm long, linear-lanceolate, green, with trichomes simple and stellate; calyx $4 \mathrm{~mm}$ long, campanulate, green with apex brownish, lobes with apex acuminate, externally sericeous, with trichomes simple, internally with trichomes only at the apex; petals flat, c. $5 \times 2 \mathrm{~mm}$, spatulate, yellow, trichomes simple internally; staminal tube c. $3 \mathrm{~mm}$ long in brevistylous flowers, c. $2 \mathrm{~mm}$ long in longistylous flowers, free portion of stamens c. $0.2 \mathrm{~mm}$ long, anthers dithecate, yellow; ovary c. $1 \times 0.5 \mathrm{~mm}$, ovoid to elipsoid, sericeous, 1 locule, 1 ovule per locule; styles c. $1.5 \mathrm{~mm}$ long in brevistylous flowers, c. $5 \mathrm{~mm}$ long in longistylous flowers, geniculated, trichomes simple sparse, stigmas ciliated. Capsule c. $5 \times 4 \mathrm{~mm}$, ovoid to ellipsoid, indehiscent, trichomes simple, aculeus absent; seeds $2 \times 1 \mathrm{~mm}$, ellipsoid, brownish, glabrous.

Specimens examined: BRAZIL, BAHIA: Paulo Afonso, Estação Ecológica Raso da Catarina, base velha $09^{\circ} 43^{\prime} 52.6^{\prime \prime} \mathrm{S} 38^{\circ} 40^{\prime} 57.1^{\prime \prime} \mathrm{W}$ 601m, 16.IV.2014, fl.; fr., J.B. Lima et al. 297, 300 (HUNEB); Povoado barrinha, 09³5'11.2"S 38 19'32.2"W 404m, 6.V.2014, fl.; fr., J.B. Lima et al. 326 (HUNEB); Jeremoabo, estrada do tamburi, em direção aos Quelés, 09057'41.9"S 38 25'32.3"W 509m, 03.IX.2012, fl.; fr., J.B. Lima et al. 48 (HUNEB); Banzaê, povoado Salgado, estrada do pau branco, 10 $35^{\prime} 55^{\prime \prime} \mathrm{S} 38^{\circ} 41^{\prime} 56^{\prime \prime} \mathrm{W}$ 306m, 15.I.2014, fl., J.B. Lima et al. 154 (HUNEB); Canudos, Parque estadual de Canudos, Vale da morte, $09^{\circ} 55^{\prime} 20.9^{\prime \prime S} 39^{\circ} 07^{\prime} 04.4^{\prime \prime} \mathrm{W} 581 \mathrm{~m}, 12 . V .2014$, fl.; fr., J.B. Lima et al. 358, 361 (HUNEB); Rodelas, Lote de Natan, perímetro irrigado 4.5, $08^{\circ} 51^{\prime} 16.7^{\prime \prime S} 38^{\circ} 44^{\prime} 49^{\prime \prime} \mathrm{W} 330 \mathrm{~m}, 03 . V I .2014$, fl.; fr., J.B. Lima et al. 403 (HUNEB); Macururé, estrada depois de Macururré em direção a Chorrochó, 0854'59.1"S 3901'04.5"W 328m, 02.VI.2014, fl.; fr., J.B. Lima et al. 397, 398 (HUNEB). 
The species is recorded in arid regions of Texas, Mexico and Central America (Amorim et al. 2009). In Brazil it occurs only in the Northeast Region in the states of Bahia, Pernambuco, Piauí and Rio Grande do Norte, in environments of Caatinga and Cerrado (Esteves 2015b). It is common in anthropized areas and widely distributed in the study area.

In the RCE the species is characterized by having canescent branches and leaves, as well as orbicular, concolorous leaves. Waltheria rotundifolia is found with flowers and fruit throughout the year.

\section{Grewioideae Hochr.}

Subshrubs to trees. Leaves simple, entire to lobed, venation palmately. Flowers actinomorphic, bissexual, diclamid, usually solitary or in inflorescence terminal or axillary. Calyx with 5 sepals, free. Corolla with 5 petals, free. Stamens five to numerous, anthers dithecate, rimose, dorsifixed. Androgynophore or gonophore present or absent. Ovary super, with one to numerous ovules per locule, placentation axile. Fruit capsule or nucaceous.

Grewioideae comprises 25 genera and 700 species, the majority of which occur in tropical regions of the New and Old World (Bayer \& Kubitzki 2003). It is represented in the study area by three genera and four species.

3.1. Corchorus hirtus L., Sp. Pl. 2(1): 747. 1762. Iconography: Shumann (1886: 26), Souza \& Esteves (2002: 339), Tschá et al. (2002: 8). Figure $3 \mathrm{Q}$

Subshrubs c. $50 \mathrm{~cm}$ tall; branches cylindrical, pubescent to glabrescent, trichomes simple sparse and a dense longitudinal line trichomes; stipules 4-5 mm long, linear, trichomes equal to branches. Leaves entires, alternate-spirallate; petiole $0.3-1.5 \mathrm{~cm}$ long, pubescent; leaf blades 1.7-5.8 $\times 0.9-2.3 \mathrm{~cm}$, ovate to elliptic-lanceolate, green, discolorous, membranaceous, base obtuse to rounded, apex acute, margin serrate, both surfaces pilose, trichomes simple sparse. Inflorescence cymose, with 2 flowers, axillary or terminal; pedicels 9-10 mm long; sepals flat 8-10 mm long, oblong, apex acuminate, externally with trichomes simple, internally glabrous; petals c. $8 \times 2.5-3$ $\mathrm{mm}$, obovate, yellow, glabrous; staminodes absents, androgynophore short, without glands, stamens $48,6-7 \mathrm{~mm}$ long, free; ovary $2-3 \times 0.8$ $1 \mathrm{~mm}$, cylindric to elliptic, sericeous, 4 locules, numerous ovules per locule; styles $5 \mathrm{~mm}$ long, stigmas capitate. Capsule $1.8-3.9 \times 0.2-0.3$ $\mathrm{cm}$, elongate-flattened, dehiscence longitudinal, hirsute, with trichomes simple; seeds c. $1.2 \times 1 \mathrm{~mm}$, tetragonal, blackened, without wings, glabrous.

Specimens examined: BRAZIL, BAHIA: Euclides da Cunha, Fazenda Binjé, do Sr. Alan, antes da barragem, 10³4'13.5"S $39^{\circ} 01^{\prime} 22.6^{\prime \prime} \mathrm{W} 383 \mathrm{~m}$, 07.VIII.2014, fl.; fr., J.B. Lima et al. 514 (HUNEB); Jeremoabo, povoado Brejinho, ao lado do cemitério, $10^{\circ} 02^{\prime} 39.5^{\prime \prime} \mathrm{S} 38^{\circ} 21^{\prime} 43.3^{\prime \prime} \mathrm{W} 310 \mathrm{~m}, 14$. VIII.2014, fl.; fr., J.B. Lima et al. 518 (HUNEB); 25.XI.2014, fr., J.B. Lima et al. 571 (HUNEB).

The species is widely distributed in South America (Robyns 1964b), especially in Brazil, where it occurs in all regions, in different environments such as Amazon Rainforest, Caatinga, Cerrado, Atlantic Forest and Swamp. The species was cataloged for the majority of the states of the Northeast Region, except Rio Grande do Norte and Piaui (Bovini 2015). It was uncommon in the RCE, found in preserved and anthropized area.
Corchorus hirtus can be recognized by its indumentum of two branches composed of sparse simple trichomes, being denser where it forms a longitudinal line; alongate-compressed fruits; and by tetragonal seeds. It was collected with flowers and fruits in June to November. According to Sampaio et al. (2005), it has apicultural and fiber production potential.

3.2. Luehea candicans Mart., Nov. Gen. Sp. Pl. 1(4): 102. 1826. Iconography: Souza \& Esteves (2002: 339). Figure 4K-M

Tree c. $5 \mathrm{~m}$ tall; branches cylindrical, young pubescent, trichomes stellate; stipules $0.4-0.8 \mathrm{~cm}$ ovate-acuminate, pubescent. Leaves entire, alternate-spirallate; petioles $0.3-0.4 \mathrm{~cm}$ long, pubescent, trichomes equal to branches; leaf blades $3.4-7 \times 2-3.6 \mathrm{~cm}$, semi-coriaceous, ovate to elliptic-lanceolate, green, discolorous, chartaceous to semicoriaceous, apex acute to acuminate, base obtuse to subchordate, margin irregulary serrate, surface adaxial rough, glabrescent with trichomes stellate sparse, surface adaxial velutinous with trichomes stellate. Solitary flower, terminal; flower passed, not examined. Capsule 1.5-2.8 $\times 0.7-1.6 \mathrm{~cm}$, obovoid to ellipsoid, loculicidal, green and tomentose when young, glabrescent and blackened when mature, trichomes stellate; seeds $0.8-1.1 \times 0.3-0.5 \mathrm{~cm}$, elliptic, winged at the apex, wing $0.5-0.8 \mathrm{~cm}$, glabrous.

Specimens examined: BRAZIL, BAHIA: Euclides da Cunha, Fazenda Brinjé, do Sr. Alan, 10³4'17.8'S 3901'08.7"W 376m, 07.VIII.2014, fr., J.B. Lima et al. 509 (HUNEB).

The species is distributed in Paraguay, Bolivia, Argentina and Brazil, where it is widely distributed in all states of the Central-West, Southeast and South regions in Cerrado and Atlantic Forest (Souza \& Esteves 2002, Esteves 2015c). It is rare in the RCE, and was collected only once. This is the first record of the species for the state of Bahia.

Luehea candicans is recognized in the study area by its tree habit; simple leaves; and solitary flower. It was collected in the RCE with passed flowers and fruits in August. The species has ornamental and apicultural potential and its wood can be used in furniture manufacturing (Souza \& Esteves 2002, Sampaio et al. 2005).

3.3. Luehea paniculata Mart., Nov. Gen. Sp. Pl. 1(4): 100. 1826. Iconography: Tschá et al. (2002: 11). Figure 5A-C

Popular name: açoita-cavalo.

Tree c. $8 \mathrm{~m}$ tall; branches cylindrical, young pubescent to tomentose, trichomes stellate, ferrugineous; stipules 2-3 mm long, linear, deciduous. Leaves entire, alternate-spirallate; petioles $0.7-1.3 \mathrm{~cm}$ long, trichomes equal to branches; leaf blades $6.5-12.8 \times 3.2-8.3 \mathrm{~cm}$, ovateoblong, green, discolorous, coriaceous, base obtuse to subchordate, apex obtuse to acute, margin serrate, surface adaxial pubescent with trichomes stellate ferrugineous, surface abaxial lanuginose canescent and trichomes stellate ferrugineous sparse. Inflorescence paniculate, terminal and axillary; flowers not observed. Capsule 1.7-2.2 $\times 0.9-1.5$ $\mathrm{cm}$, oboval, loculocide, pubescent; seeds $8-9 \times 3.8-4 \mathrm{~mm}$, elliptic, apex winged, wing c. $6 \mathrm{~mm}$ long.

Specimens examined: BRAZIL, BAHIA: Cícero Dantas, estrada do Sapé, $10^{\circ} 19^{\prime} 32.5^{\prime \prime S} 38^{\circ} 35^{\prime 2} 26.2^{\prime \prime} \mathrm{W} 622 \mathrm{~m}$, 05.VIII.2014, bt.; fr., J.B. Lima et al. 492 (HUNEB).

The species is distributed in Peru, Bolivia, Paraguay, Brazil, Argentina and Uruguay (Milward-de-Azevedo \& Valente 2005). 
In Brazil it has been recorded in all regions and in various environments such as the Amazon Rainforest, Caatinga, Cerrado, Atlantic Forest and the Pantanal. In the Northeast Region the species does not occur in the states of Rio Grande do Norte and Sergipe (Esteves 2015c). It is rare in the RCE, and was collected only once.

Luehea paniculata is recognized in the area by its tree habit; simple leaves canescent on the abaxial surface; and paniculiform inflorescences. It was collected in the study area with buds and fruits only in August. It has wood, medicinal and apicultural potential (Guimarães et al. 1993, Milward-de-Azevedo \& Valente 2005, Sampaio et al. 2005).

3.4. Triumfetta semitriloba Jacq., Enum. Syst. P1. 22. 1760. Iconography: Lay (1950: 374), Souza \& Esteves (2002: 339), Tschá et al. (2002: 15), Alves et al. (2011: 15). Figure 3R

Popular name: carrapicho.

Subshrubs 1.3-1.5 m tall; branches cylindrical, pubescent, trichomes stellate; stipules 4-6 mm long, linear, trichomes equal to branches. Leaves entire to semi-trilobate, alternate-spirallate; petiole $2-3 \mathrm{~cm}$ long, tomentose; leaf blades 4-9 $\times 2.5-7.5 \mathrm{~cm}$, largely ovate to elliptic, green, discolorous, membranaceous, base truncate to subchordate, apex acuteacuminate, margin irregulary serrate, both surfaces pubescent, with trichomes stellate. Inflorescence cymose, cymule with 3 to 5 flowers, axillary or terminal; pedicels $2-4 \mathrm{~mm}$ long; sepals cucullate $5-8 \mathrm{~mm}$ long, oblong, ellipsoid, with apicule at the extremities, externally with trichomes stellate, internally glabrous; petals $4.5-6 \times 1-2 \mathrm{~mm}$, ellipticspatulate, yellow, ciliated; staminodes absents, gonophore $2-3 \mathrm{~mm}$ long with glands elliptic, stamens $12-15,3.5-5 \mathrm{~mm}$ long, free; ovary 1-2×c.1 mm, globose, pubescent, locules 3-4, 2 ovules per locule; styles 4-5.5 mm long, stigmas acute. Nucaceous c. $1 \times 1 \mathrm{~cm}$, including the apicule, globose, indehiscent, glabrescent to pubescent, spine uncinate with trichomes simple; seeds c. $0.2 \times 0.1 \mathrm{~mm}$, ellipsoid, beige to brown, without wings, glabrous.

Specimens examined: BRAZIL, BAHIA: Jeremoabo, APA Serra Branca, baixa grande depois dos Quelés, roça de Mané de Chico, 09 58'31"S 38 27'01"W 564m, 03.IX.2012, fl.; fr., D.D. Vieira et al. 386 (HUNEB), J.B. Lima et al. 53 (HUNEB); Baixa dos Quelés, depois da porteira, próximo a casa de Antônio Rouxinho, 0957'30.3"S $38^{\circ} 26^{\prime} 20^{\prime \prime} \mathrm{W} 504 \mathrm{~m}, 12 . X I .2013$, fl., J.V. Santos et al. 96 (HUNEB); Estrada saíndo dos Quelés, sentido ESEC, 0956'45.7"S 38²7'30.1"W $607 \mathrm{~m}, 29$. VII.2009, fl., T.M. Silva et al. 131 (HUNEB); Povoado Brejinho, 1002'32"S 38 21'44.2"W 307m, 31.VII.2014, fl.; fr., J.B. Lima et al. 459 (HUNEB); Estrada depois da baixa da forra, indo para Quelés, $10^{\circ} 02^{\prime} 22.7^{\prime \prime S} 38^{\circ} 21^{\prime} 45.5^{\prime \prime} \mathrm{W} 315 \mathrm{~m}, 31 . \mathrm{VII} .2014$, fl.; fr., J.B. Lima et al. 465 (HUNEB); Baixa do tamburi, 09 $57^{\prime} 46^{\prime \prime} \mathrm{S} 38^{\circ} 26^{\prime} 12^{\prime \prime} \mathrm{W}$ 478m, 14.VIII.2014, fl.; fr., J.B. Lima et al. 520 (HUNEB); Cícero Dantas, boqueirão, em frente a casa de Jorge, $10^{\circ} 33^{\prime} 21.1^{\prime \prime} \mathrm{S} 38^{\circ} 24^{\prime} 29^{\prime \prime} \mathrm{W}$ 406m, 04.VIII.2014, fl.; fr., J.B. Lima et al. 477 (HUNEB); estrada do Sapé, $10^{\circ} 19^{\prime} 32.5^{\prime \prime S} 38^{\circ} 35^{\prime 2} 26.2^{\prime \prime} \mathrm{W} 622 \mathrm{~m}, 05 . V I I I .2014$, fl.; fr., J.B. Lima et al. 493 (HUNEB).

It has a Pantropical distribution (Barroso 1978). It occurs throughout Brazil, with the exception of the states of Acre, Rondônia, Roraima, Amapá and Tocantins, in the Amazon Rainforest, Caatinga, Cerrado and Atlantic Forest (Esteves 2015d). Well collected in the RCE, the species is known only in the EPASB (Jeremoabo) and the municipality of Cícero Dantas.
Triumfetta semitriloba is recognized in the study area by the presence of 12-15 stamens; apically ellipsoid sepals; androgynophore with elliptical glands; and glabrescent to pubescent fruits but with uncinate spines containing simple trichomes. It was found with flowers and fruit throughout the year. The species has apicultural potential (Sampaio et al. 2005).

\section{Helicterioideae (Schott e Endl.) Meisn.}

Shrubs. Leaves simple, entire, venation palmately. Flowers zygomorphic, bissexual, diclamid, solitary or in inflorescence terminal or axillary. Calyx gamosepalous with 5 lobes. Corolla with 5 petals, free. Androgynophore present. Stamens 10, free; staminode 5, anthers dithecate, rimose, dorsifixed. Ovary super, with numerous ovules per locule, placentation axile. Fruit capsule spirallate.

The subfamily includes six genera and 70 species distributed in the tropical regions of the New and Old World (Bayer \& Kubitzki 2003). Two species of the subfamily are recorded in the ecoregion.

4.1. Helicteres eichleri K. Shum., Fl. Bras. (Martius) 12(3): 16. 1886. Iconography: Cristóbal (2001: 103). Figures 3S; 5D-G

Shrubs 1.8-2 m tall; branches cylindrical, tomentose, trichomes stellate, more dense in the extremities; stipules $1-1.5 \mathrm{~cm}$ long, linear, trichomes equal to branches. Leaves alternate-spirallate; petiole 1-2 $\mathrm{cm}$ long, tomentose; leaf blades $3-8 \times 2-5 \mathrm{~cm}$, ovate to elliptic, green, discolorous, chartaceous, base rounded to subchordate, apex acute, margin serrated, both surfaces pubescent, with trichomes stellate, more dense on the abaxial surface. Inflorescence cymose, 2-flowers, axillary or oppositifolious; 2 profiles per flower, c. $1.3 \mathrm{~cm}$ long, linear, tomentose; pedicels $0.4-0.6 \mathrm{~cm}$ long, nectaries absent; calyx $1.8-2.5 \mathrm{~cm}$ long, tubulous, erect, red, lobes with apex acute-acuminate, externally pubescent, with trichomes stellate, internally with trichomes only at the apex; petals $4-5 \times$ c. $5 \mathrm{~mm}$, included, reduced to flabeliforms claw, alb, glabrous; androgynophore 3-4 cm long, erect, with trichomes stellate; staminodes $2 \times 2.5 \mathrm{~mm}$, elliptic; stamens $1-1.5 \mathrm{~mm}$ long; ovary c. $1.5 \times 1$ $\mathrm{mm}$, ovoid, tomentose, 5 locules, c. 12 ovules per locule; styles $2.5-3$ mm long, stigmas acute. Capsule $1.5-2.5 \times 0.8-1 \mathrm{~cm}$, cylindric, slightly ovoid, spirallate until a half, indehiscent, with trichomes stellate; seeds c. $2.5 \times 2 \mathrm{~mm}$, ellipsoid, dark brown, glabrous.

Specimens examined: BRAZIL, BAHIA: Jeremoabo, APA Serra Branca, estrada sentido Serra do Navio, 0951'58.1"S 38 38'46.9"W 482m, 03.XI.2011, fl.; fr., J.B. Lima et al. 11 (HUNEB); estrada sentido Serra do Navio, depois do dedo de Deus, 09² $52^{\prime} 43.4^{\prime \prime} \mathrm{S} 38^{\circ} 39^{\prime} 14.5^{\prime \prime} \mathrm{W}$ 463m, 11.II.2014, fl.; fr., J.B. Lima et al. 187 (HUNEB); 24.XI.2014, fl.; fr., J.B. Lima et al. 578 (HUNEB); estrada principal sentido Serra do Navio, 0952'59"S 38³9'45"W 453m, 06.VI.2014, fl.; fr., J.B. Lima et al. 415 (HUNEB); Trilha do morrote, 0952'16.7"S 38 38'43.9"W 474m, 30.VII.2014, fl.; fr., J.B. Lima et al. 456 (HUNEB); Trilha do araçá, 9,5 km de distância da base da APA, 0952'49.1"S 38 38'13.5"W 535m, 08.V.2008, fl.; fr., M.V. Romão et al. 129 (HUNEB); Estrada sentido serra branca, 0952'51.9"S 38³9'28.9"W 487m, 10.XII.2008, fl.; fr., M.V. Romão et al. 424 (HUNEB); Canudos, Parque estadual de Canudos, marco da degola, 09²54'54.6"S 3907'05.7"W 379m, 10.V.2008, fl.; fr., M.V. Romão et al. 179 (HUNEB).

Restricted to the states of Alagoas, Bahia, Maranhão, Paraíba, Pernambuco and Sergipe, Helicteres eichleri is an endemic specie 
to Brazil and occurs in the Caatinga and Atlantic Forest (Cristóbal 2001, Esteves 2015e). In the RCE the species occurs only in areas of preserved Caatinga in the EPASB (Jeremoabo) and of State Park of Canudos (SPC).

It is distinguished from its congeners in the study area by having a straight calyx; included petals reduced to flabelliform claws; and a short androgynophore reaching up to $4 \mathrm{~cm}$. It was found with flowers and fruits throughout the year.

4.2. Helicteres velutina K.Schum., Fl. Bras. (Martius) 12(3): 22. 1886. Iconography: Cristóbal (2001: 61), Cristóbal (2006: 109). Figure 3T

Shrubs 1.8-2.2 m tall; branches cylindrical, velutinous, trichomes stellate; stipules 5-7 mm long, linear, trichomes equal to branches. Leaves alternate-spirallate; petiole $1-1.5 \mathrm{~cm}$ long, tomentose; leaf blades $3.5-9 \times 2-6.5 \mathrm{~cm}$, ovate to elliptic, green, discolorous, chartaceous, base subchordate, apex acute, margin serrate, both surfaces velutinous, with trichomes stellate, more dense on abaxial surface. Inflorescence cymose, 2-flowers, axillary and terminal; 2 profiles per flower, $1-1.2 \mathrm{~cm}$ long, linear; pedicels $0.5-0.7 \mathrm{~cm}$ long, $1-3$ nectaries; calyx $1.2-2.5 \mathrm{~cm}$ long, tubulous-campanulate, geniculated at the the base, red with base beige, lobes with apex acuminate, externally pubescent, with trichomes stellate, internally with trichomes only at the apex; petals $2-3.5 \times 0.8-1.2$ $\mathrm{cm}$, unguiculate, orange to red, glabrous, claw 12-17×1-2 mm, wings fringes; androgynophore $6-8 \mathrm{~cm}$ long, curved, glabrous; staminodes c. $2.5 \mathrm{~mm}$, elliptic; stamens $2-3 \mathrm{~mm}$ long; ovary $1.5-2 \mathrm{~mm}$, ovoid, tomentose, 5 locules, c. 16 ovules per locule; styles $2.5-4 \mathrm{~mm}$ long, stigmas acute. Capsule 1.5-3×1-1.5 cm, cylindrical, spiraled until a half, dehiscencia apical, with trichomes stellate; seeds $2.1-2.8 \times 1.5-2$ $\mathrm{mm}$, tetragonal, beige with brown macules, glabrous.

Specimens examined: BRAZIL, BAHIA: Paulo Afonso, Estação Ecológica Raso da Catarina, trilha do tansecto, 09³9'50.7"S $38^{\circ} 28^{\prime} 01.4^{\prime \prime} \mathrm{W}$, 17.VIII.2010, fl.; fr., C.L.S.B. Correia et al. 175 (HUNEB); Trilha próximo a casa sede do ICMBio, 09³9'84.2"S $38^{\circ} 28^{\prime} 00.6^{\prime \prime} \mathrm{W} 592 \mathrm{~m}$, 4.IV.2011, fl., C.L.S.B. Correia et al. 434 (HUNEB); Trilha sentido casa $02,09^{\circ} 50^{\prime} 11.4^{\prime \prime} \mathrm{S} 38^{\circ} 29^{\prime} 47.3^{\prime \prime} \mathrm{W} 670 \mathrm{~m}$, 4.V.2011, fl., C.L.S.B. Correia et al. 442 (HUNEB); Trilha sentido pedra da janela, $09^{\circ} 40^{\prime} 00.8^{\prime \prime} \mathrm{S} 38^{\circ} 27^{\prime} 59.5^{\prime \prime} \mathrm{W} 575 \mathrm{~m}$, 25.VII.2011, fl.; fr., C.L.S.B. Correia et al. 502 (HUNEB); Trilha sentido mata da Pororoca, próximo a casa do Sr. Divá, 09²'23.9"S 38²9'46.1"W 645m, 27.VII.2011, fl.; fr., C.L.S.B. Correia et al. 526 (HUNEB); Após a mata da Pororoca, 0948'46.3"S 38²9'31"W 698m, 18.III.2014, fl.; fr., J.B. Lima et al. 194 (HUNEB); Estrada em direção a base velha, 0951'38.7"S 38²9'29.3"W 635m, 18.III.2014, fl.; fr., J.B. Lima et al. 196 (HUNEB); Trilha sentido Pororoca, depois da casa do Sr. Divá, 0945'12.5"S $38^{\circ} 29^{\prime 2} 29.2^{\prime \prime} \mathrm{W} 655 \mathrm{~m}, 15 . I V .2014$, fl.; fr., J.B. Lima et al. 274 (HUNEB); 24.XI.2014, fl.; fr., J.B. Lima et al. 570 (HUNEB); Base nova (3), 09³4'51.5"S 38 29'27.8"W 622m, 03.IX.2014, fl.; fr., J.B. Lima et al. 536 (HUNEB); ESEC, mata da Pororoca, 0948'28.1"S 38 29'30.9"W 699m, 19.V.2010, fl.; fr., M.V. Romão et al. 606 (HUNEB); 0948'39.6"S $38^{\circ} 29^{\prime} 31^{\prime \prime} \mathrm{W} 707 \mathrm{~m}, 24 . I X .2013$, fl.; fr., J.B. Lima et al. 105 (HUNEB); 07.V.2014, fl.; fr., J.B. Lima et al. 337 (HUNEB); 09.VI.2014, fl.; fr., J.B. Lima et al. 422 (HUNEB); 21.VII.2014, fl.; fr., J.B. Lima et al. 438 (HUNEB); Cícero Dantas, estrada do Sapé, 10¹9'27"S 38³5'52.9"W 611m, 5.VIII.2014, fl.; fr., J.B. Lima et al. 489 (HUNEB); Canudo,
Estação Biológica de Canudos, depois do riacho em direção ao saco 1, $09^{\circ} 57^{\prime} 05.7^{\prime \prime} \mathrm{S} 39^{\circ} 00^{\prime} 07.9^{\prime \prime} \mathrm{W} 413 \mathrm{~m}, 2$ 27.III.2014, fl.; fr., J.B. Lima et al. 248 (HUNEB); Saindo do saco 1, em direção ao saco 2, depois do Jatobá, 0957'06.3"S 38 59'58.4"W 403m, 14.V.2014, fl.; fr., J.B. Lima et al. 382 (HUNEB); Jeremoabo, APA Serra Branca, estrada que vai da ESEC em direção ao povoado Quelés, $09^{\circ} 53^{\prime} 01.8^{\prime \prime} \mathrm{S} 38^{\circ} 32^{\prime} 39.5^{\prime \prime} \mathrm{W} 650 \mathrm{~m}$, 22.IX.2010, fl.; fr., D.D. Vieira et al. 82 (HUNEB); Estrada principal de Quelés, em direção a divisa APA-ESEC, 0957'53"S 38²6'30"W 500m, 17.VI.2011, fl.; fr., D.D. Vieira et al. 177 (HUNEB); Caminho da ESEC em direção a Quelés, 0957'21.5"S 38²6'22.5"W, 502m, 09.IX.2009, fl.; fr., M.V. Romão et al. 546 (HUNEB); 0957'28.9"S 38²6'18.6"W 502m, 09XII.2009, fl.; fr., M.V. Romão et al. 563 (HUNEB); Estrada do tamburi, próximo a baixa dos Quelés, 09 $57^{\prime} 43^{\prime \prime} \mathrm{S} 38^{\circ} 25^{\prime} 33.3^{\prime \prime} \mathrm{W}$ 514m, 09.VII.2012, fl.; fr., J.B. Lima et al. 23 (HUNEB); Depois de Olho D'água dos negros, $10^{\circ} 01^{\prime} 00.7^{\prime \prime S} 38^{\circ} 22^{\prime} 30^{\prime \prime} \mathrm{W} 438 \mathrm{~m}, 5 . \mathrm{VI} .2014$, fl.; fr., J.B. Lima et al. 411 (HUNEB).

Endemic to Brazil, Helicteres velutina occurs in the Northeast (Bahia, Ceará, Pernambuco) and Southeast (Minas Gerais) regions, in the areas of Caatinga, Cerrado and Atlantic Forest (Cristóbal 2001, Esteves 2015e). In the RCE, the species is widely distributed in areas of preserved Caatinga.

Helicteres velutina is recognized in the RCE by its velutinous branches, leaves and fruits; calyx geniculate at the base; and by a curved and long androgynophore attaining $8 \mathrm{~cm}$ in length. It possessed flowers and fruits throughout the year.

\section{Supplementary material}

The following online material is available for this article:

Appendix 1 - List of additional material examined.

\section{Acknowledgements}

The authors thank to the Fundação de Amparo à Pesquisa do Estado da Bahia (FAPESB, PET \#0023/2007) and to the Conselho Nacional de Desenvolvimento Científico e Tecnológico (CNPq Proc. \#552589/2011-0) for financial support. To Instituto Chico Mendes (ICMBio) for their support during field work. The first author thanks the Coordenação de Aperfeiçoamento de Pessoal de Nível Superior (CAPES) for the scholarship. To Jefferson Guedes de Carvalho Sobrinho (UNIVASF) for the concession of bibliographies, the curators and technicians of the herbaria that were visited for their readiness during the consultation of the collections and Klei Sousa for the botanical illustrations.

\section{Author Contributions}

Jéssica Batista Lima: Contribution to the acquisition of data; analysis and interpretation of data; work of writing and conception and design work.

Massimo Giuseppe Bovini: Contribution to the interpretation of data and critical review adding intellectual content.

Adilva de Souza Conceição: Contribution to the acquisition of data; analysis and interpretation of data; work of writing; critical review adding intellectual content and conception and design work. 


\section{Conflicts of interest}

The authors declare that they have no conflict of interest related to the publication of this manuscript.

\section{References}

ALVERSON, W.S., WHITLOCK, B.A., NYFFELER, R., BAYER, C. \& BAUM, D.A. 1999. Phylogeny of the core Malvales: evidence from $n d h \mathrm{~F}$ sequence data. Amer. J. Bot. 86(10):1774-1486.

ALVES, I.M., DANTAS, I.C., MELO, J.I.M. \& FELISMINO, D.C. 2011. A Família Malvaceae sensu lato em uma área do agreste paraibano, Nordeste do Brasil. BioFar. 06(01):1-20.

AMORIM, B.S. 2013. Byttneioideae. In Flora de Sergipe (A.P.N. Prata, M.C.E. Amaral, M.C.V. Farias, M.V Alves, eds). Gráfica e Editora Triunfo, Aracaju, 1:326-335.

AMORIM, B.S., SAUNDERS, J.G., DU BOCAGE NETA, A.L. \& ALVES M. 2009. Malvaceae s.1. In Flora de Mirandiba. (M. Alves, M.F. Araujo, J.R. Maciel, S. Martins, eds). Associação Plantas do Nordeste, Recife. p. 245-262.

BARROSO, G.M., GUIMARÃES, E.F., ICHACO, C.L.F., COSTA, C.G. \& PEIXOTO, A.L. 1978. Sistemática de angiosperma do Brasil. Universidade de São Paulo, São Paulo.

BAUM, D.A., SMITH, S.D.W., YEN, A., ALVERSON, W.S., NYFFELER, R., WHITLOCK, B.A. \& OLDHAM, R.L. 2004. Phylogenetic relationship of Malvatheca (Bombacoideae and Malvoideae; Malvaceae sensu lato) as inferred from plastid DNA sequences. Am. J. Bot. 91(11):1863-1871.

BAYER, C., FAY, M.F., DE BRUIJIN, A.Y., SAVOLAINEN, V., MORTON, C.M., KUBITZKI, K., ALVERSON, W.S. \& CHASE, M.W. 1999. Support for an expanded family concept of Malvaceae within a recircunscribed order Malvales: a combined analysis of plastid $a t p \mathrm{~B}$ and $r b c \mathrm{~L}$ DNA sequences. Bot. J. Linn. Soc. 129 (4):267-303.

BAYER, C. \& KUBITZKI, K. 2003. Malvaceae. In The families and genera of vascular plants. flowering plants dicotyledons. Malvales, Capparales and non-betalain Caryophyllales. (K. Kubitzki \& C. Bayer, eds). Springer-Verlag, Berlin. v.5, p.225-311.

BFG - The Brazil Flora Group 2015. Growing knowledge: an overview of seed plant diversity in Brazil. Rodriguésia 66(4):1085-1113.

BOVINI, M.G. 2015. Corchorus. In Lista de Espécies da Flora do Brasil. Jardim Botânico do Rio de Janeiro. http://floradobrasil.jbrj.gov.br/jabot/ floradobrasil/FB9042 (last access in 13/04/2018)

BOVINI, M.G., ESTEVES, G., DUARTE, M.C., TAKEUCHI, C., KUNTZ, J. 2015. Malvaceae. In Lista de Espécies da Flora do Brasil. Jardim Botânico do Rio de Janeiro. http://floradobrasil.jbrj.gov.br/jabot/floradobrasil/FB156. (last access in 13/04/2018).

CARVALHO-SOBRINHO, J.G. \& QUEIROZ, L.P. 2010 Three new species of Pseudobombax (Malvaceae, Bombacoideae) from Brazil. Novon 20(1):13-20.

CARVALHO-SOBRINHO, J.G. 2006. O gênero Pseudobombax Dugand no estado da Bahia. Dissertação de Mestrado, Universidade Estadual de Feira de Santana, Feira de Santana.

CARVALHO-SOBRINHO, J.G., ALVERSON, W.S., MOTA, A.C., MACHADO, M.C. \& BAUM, D.A. 2014. A new deciduous species of Pachira (Malvaceae: Bombacoideae) from a seasonally dry tropical forest in Northeastern Brazil. Syst. Bot. 39(1):260-267.

CRISTÓBAL, C.L. \& TRESSENS, S. 1986. Sterculiaceae. In Flórula de Mucugê, Chapada Diamantina, Bahia, Brazil (R.M. Harley \& N.A. Simmons, eds). Royal Botanic Gardens, Kew, p. 192-195.

CRISTÓBAL, C.L. 1960. Revisión del género Ayenia L. (Sterculiaceae). Opera Lilloana 4:1-230

CRISTÓBAL, C.L. 1976. Estudio taxonomico del género Byttneria Loefl. (Sterculiaceae). Bonplandia 2:5-428.

CRISTÓBAL, C.L. 1981. Rayleya, nueva Sterculiaceae de Bahia, Brasil. Bonplandia 5(8):43-50.

CRISTÓBAL, C.L. 1998. Flora Fanerogámica Argentina: Sterculiaceae. Proflora, Cordoba, p. 1-32.
CRISTÓBAL, C.L. 2001. Taxonomia del genero Helicteres (Sterculiaceae), revisión de las especies americanas. Bonplandia 11(1-4):1-206.

CRISTÓBAL, C.L. 2006. Flora de Grão-Mogol, Minas Gerais: Sterculiaceae. Bol. Bot. Univ. São Paulo 24:107-113.

CRISTÓBAL, C.L. 2007. Sterculiaceae de Paraguay. I. Ayenia, Byttneria, Guazuma, Helicteres, Melochia y Sterculia. Bonplandia 16(1-2):5-142.

CRISTÓBAL, C.L., ESTEVES, G.L. \& SAUNDERS, J.G. 1995. Sterculiaceae. In Flora of the Pico das Almas, Chapada Diamantina, Bahia, Brazil (B. Stannard, org). Royal Botanic Gardens, Kew, p. 602-607.

CRONQUIST, A. 1988. The evolution and classification of flowering plants. The New York Botanical Garden, New York

CRUZ, F.R. \& ESTEVES, G.L. 2009 Sterculiaceae. In Flora Fanerogâmica do Estado de São Paulo. (M.G.L. Wanderley, G.J. Shepherd, T.S. Melhem, A.M. Giulietti, S.E. Martins, eds). São Paulo, Instituto de Botânica, FAPESP, 6:257-284.

CRUZ, F.R. 2007. Sterculiaceae Vent. no estado de São Paulo. Dissertação de Mestrado, Instituto de Botânica da Secretaria de Estado do Meio Ambiente, São Paulo.

DAHLGREN, R.M.T. 1980. A revised system of classification of angiospems. Bot. J. Linn. Soc. 80(2):91-124.

DU BOCAGE, A.L. \& SALES, M.F. 2002. A família Bombacaceae Kunth no estado de Pernambuco, Brasil. Acta Bot. Bras. 16(2):123-139.

DUARTE, M.C. 2006. Diversidade de Bombacaceae Kunth no estado de São Paulo. Dissertação de Mestrado, Instituto de Botânica da Secretaria de Estado do Meio Ambiente, São Paulo.

DUARTE, M.C. 2010. Análise filogenética de Eriotheca Schot \& Endl. e gêneros afins (Bombacoideae, Malvaceae) e estudo taxonômico de Eriotheca no Brasil. Tese de Doutorado, Instituto de Botânica da Secretaria de Estado do Meio Ambiente, São Paulo.

DUARTE, M.C. 2015a. Ceiba. In Lista de Espécies da Flora do Brasil. Jardim Botânico do Rio de Janeiro. http://floradobrasil.jbrj.gov.br/jabot/ floradobrasil/FB9032 (last access in 13/04/2018).

DUARTE, M.C. 2015b. Pachira. In Lista de Espécies da Flora do Brasil. Jardim Botânico do Rio de Janeiro. http://floradobrasil.jbrj.gov.br/jabot/ floradobrasil/FB23584 (last access in 13/04/2018).

DUARTE, M.C. 2015c. Pseudobombax. In Lista de Espécies da Flora do Brasil. Jardim Botânico do Rio de Janeiro. http://floradobrasil.jbrj.gov.br/jabot/ floradobrasil/FB9193 (last access in 13/04/2018).

DUARTE, M.C., ESTEVES, G.L. \& SEMIR, J. 2007. Bombacaceae. In Flora Fanerogâmica do Estado de São Paulo (M.G.L. Wanderley, G.J. Shepherd, T.S. Melhem, A.M. Giulietti \& S.E. Martins, eds). São Paulo, Instituto de Botânica, FAPESP, 5: 21-37.

ESTEVES, G.L. 1986. A ordem Malvales na Serra do Cipó, Minas Gerais, Brasil. Dissertação de Mestrado, Universidade de São Paulo, São Paulo.

ESTEVES, G.L. 2005. Flora da Reserva Ducke, Amazonas, Brasil: Bombacaceae. Rodriguésia 56(86):115-124

ESTEVES, G.L. 2015a. Ayenia. In Lista de Espécies da Flora do Brasil. Jardim Botânico do Rio de Janeiro. http://floradobrasil.jbrj.gov.br/jabot/ floradobrasil/FB25729 (last access in 13/04/2018).

ESTEVES, G.L. 2015b. Waltheria. In Lista de Espécies da Flora do Brasil. Jardim Botânico do Rio de Janeiro. http://floradobrasil.jbrj.gov.br/jabot/ floradobrasil/FB9270 (last access in 13/04/2018).

ESTEVES, G.L. 2015c Luehea. In Lista de Espécies da Flora do Brasil Jardim Botânico do Rio de Janeiro. http://floradobrasil.jbrj.gov.br/jabot/ floradobrasil/FB9091 (last access in 13/04/2018).

ESTEVES, G.L. 2015d. Triumfetta. In Lista de Espécies da Flora do Brasil. Jardim Botânico do Rio de Janeiro. http://floradobrasil.jbrj.gov.br/jabot/ floradobrasil/FB9260 (last access in 13/04/2018).

ESTEVES, G.L. 2015e. Helicteres. In Lista de Espécies da Flora do Brasil. Jardim Botânico do Rio de Janeiro. http://floradobrasil.jbrj.gov.br/jabot/ floradobrasil/FB9066 (last access in 13/04/2018).

FERNANDES-JUNIOR, A.J. \& CRUZ, A.P.O. 2018. Flora of the canga of the Serra dos Carajás, Pará, Brazil: Malvaceae. Rodriguésia 69(3):1237-1254. 
FERNANDES-JUNIOR, A.J. \& KONNO, T.U.P. 2017. Malvaceae of Parque Estadual do Ibitipoca, Minas Gerais State, Brazil. Hoehnea 44(4):505-523.

FOSBERG, F.R. \& SACHET, M.H. 1965. Manual for tropical herbaria. Utrecht, Netherlands.

GIBBS, P.E. \& SEMIR, J. 2003. A Taxonomic Revision of the genus Ceiba Mill. (Bombacaceae). Anal. Jard. Bot. Madrid 60(2):259-300.

GOLDBERG, A. 1967. The genus Melochia L. (Sterculiaceae). Contr. U.S. Natl. Herb. 34(5):191-363.

GONÇALEZ, V.M. 2018. Melochia. In Flora do Brasil 2020 em construção. Jardim Botânico do Rio de Janeiro. http://floradobrasil.jbrj.gov.br/reflora/ floradobrasil/FB25754 (last access in 13/04/ 2018).

GONÇALEZ, V.M. \& ESTEVES, G.L. 2017. Estudo taxonômico de Melochia L. (Byttnerioideae, Malvaceae) na região Sudeste do Brasil. Hoehnea 44(3):431-448

GONÇALVES, E.G. \& LORENZI, H. 2011. Morfologia vegetal: organografia e dicionário ilustrado de morfologia das plantas vasculares. 2 ed. Instituto Plantarum, São Paulo.

GUIMARÃES, E.F., MAUTONE, L., RIZZINI, C.T. \& MATTOS FILHO, A., 1993. Árvores do Jardim Botânico do Rio de Janeiro. Ed. Lidador, Rio de Janeiro.

HARRIS, J. \& HARRIS, M. 2001. Plant identification terminology: an illustrated glossary. 2. ed. Spring Lake Publishing, Utah.

JUDD, W.S. \& MANCHESTER, S.R. 1997. Circumscription of Malvaceae (Malvales) as determined by a preliminary cladistic analysis of morphological, anatomical, palynological, and chemical characters. Brittonia 49(3):384-405.

JUDD, W.S., CAMPBELl, C.S., KELlOG, E.E., STEVENS, P. \& DONOGHUE, M.J. 2009. Sistemática Vegetal um enfoque filogenético. 3 ed. Artmed, Porto Alegre.

KINUPP, V.F. \& LORENZI, H. 2014. Plantas alimentícias não conveincionais (PANC) no Brasil. Instituto Plantarum, São Paulo.

LAY, K.K. 1950. The American Species of Triumfetta L. Ann. Mo. Bot. Gard 37:315-395.

LORENZI, H. \& MATOS, F.J.A. 2008. Plantas Medicinais no Brasil. 2 ed. Instituto Plantarum, São Paulo.

MILWARD-DE-AZEVEDO, M.A. \& VALENTE, M.C. 2005. Tiliaceae da mata de encosta do Jardim Botânico do Rio de Janeiro e arredores, Rio de Janeiro, RJ. Arquivos do Museu Nacional 63:631-637.

MORI, S.A., SILVA, L.A.M., LISBOA, G. \& CORADIN, L. 1989. Manual de manejo do herbário fanerogâmico. Ilhéus: Centro de Pesquisa do Cacau.

NYFFELER, R., BAYER, C., ALVERSON, W.S., YEN, A., WHITLOCK, B.A., CHASE, M.W. \& BAUM, D.A. 2005. Phylogenetic analysis of the Malvadendrina clade (Malvaceae s.l.) based on plastid DNA sequences. Org., Divers. \& Evol. 5:109-123.

PAES, M.L.N. \& DIAS, I.F.O. 2008. Plano de manejo: Estação Ecológica Raso da Catarina. Brasília: Ibama.

ROBYNS, A. \& CUATRECASAS, J. 1964. Sterculiaceae. In Flora of Panamá (Woodson Jr, R.E., Schery, R.W. \& Robyns, A., eds.). Ann. Mo. Bot. Gard, St. Louis, 51:69-107.

ROBYNS, A. 1963. Essai de Monographie du genre Bombax s.l. (Bombacaceae) Bull. Jard. Bot. Etat 33(1):1-311.

ROBYNS, A. 1964a. Bombacaceae. In Flora of Panamá (Woodson Jr, R.E., Schery, R.W. \& Robyns, A., eds.). Ann. Mo. Bot. Gard, St. Louis, 51:37-68.

ROBYNS, A. 1964b. Tiliaceae. In Flora of Panamá (Woodson Jr, R.E., Schery, R.W. \& Robyns, A., eds.). Ann. Mo. Bot. Gard, St. Louis, 51:1-35.

RONDÓN, J.B. \& CAMPOS, L.J.C. 2006. Clave preliminar para identificar especies de la familia Sterculiaceae en Venezuela. Universidad de Oriente, Venezuela, 18(2):142-152.

RONDÓN, J.B. 2007. Estudio taxonómico del género Melochia L. (Sterculiaceae) en el estado Sucre, Venezuela. Revista UDO Agrícola 7(1):122-137.
RONDÓN, J.B. 2008. Revisión taxonómica del género Waltheria L. (Sterculiaceae) en Venezuela, Ernstia 18(1):7-36.

RONDÓN, J.B. 2009. Revisión taxonómica del género Melochia L. (Sterculiaceae) en Venezuela. Acta Bot. Venez. 32(1):1-61.

SAMPAIO, E.V.S.B. 1995. Overview of the Brazilian Caatinga. In Seasonally dry tropical forests (S.H. BULLOCK, H.A. MOONEY, E. MEDINA orgs) Cambridge, Cambridge Univ. Press, p. 35-63.

SAMPAIO, E.V.S.B., PARYEN, F.G.C., FIGUEIRÔA, J.M. \& JUNIOR, A.G.S. 2005. Espécies da flora nordestina de importância econômica potencial Associação Plantas do Nordeste, Recife.

SAUNDERS, J.G. 1995. Systematics and evolution of Waltheria L (Sterculiaceae, Hermannieae). Tese de Doutorado, The University of Texas at Austin, Austin, v.1-3

SBB 2018. Rede Brasileira de Herbários. http://www.botanica.org.br/rbhcatalogo (last access in 13/04/2018).

SAINT-HILAIRE, A. de. 1825-1827. Malvaceae and Tiliaceae. In Flora brasiliæ meridionalis (A. de Saint-Hilaire, ed). A. Belin, Paris, V. 1, No 14, p. 138-295.

SCHUMANN, K. 1886. Bombacaceae, Sterculiaceae and Tiliaceae. In Flora Brasiliensis (C.F.P. Martius, A.G. Eichler \& I. Urban, eds.). F. Fleischer, Lipsiae, V.12, pars 3, p.1-250.

SOUZA, B.M. \& ESTEVES, G.L. 2002. Tiliaceae. In Flora Fanerogâmica do Estado de São Paulo (M.G.L. Wanderley, G.J. Shepherd, T.S. Melhem, A.M. Giulietti \& S.E. Martins, eds). São Paulo, Instituto de Botânica, FAPESP, 2: 331-342.

SOUZA, V.C. \& LORENZI, H. 2012. Botânica Sistemática: Guia ilustrado para identificação das famílias de Fanerógamas nativas e exóticas no Brasil, baseado em APG III. 3 ed. Instituto Plantarum, Nova Odessa.

SZABO, A.V., ROCHA, A.C.S., TOSATO, J.A.C., BARROSO, W. 2007. Área de proteção ambiental (APA) Serra Branca Raso da Catarina. In As Caatingas: debates sobre a ecorregião do Raso da Catarina (J. MARQUES org.). Paulo Afonso, Fonte Viva, p. 21-40.

TAKHTAJAN, A.L. 1980. Outline of the classification of the flowering plants (Magnoliophyta). Bot. Rev. 46(3):225-359.

THIERS, B. 2018 [continuously updated]. Index Herbariorum: a global directory of public herbaria and associated staff. New York Botanical Garden's Virtual Herbarium. http://sweetgum.nybg.org/ih/ (last access in 13/04/ 2018).

TRICART, J. 1972. The landforms of the humid tropics, forests and savannas. Geographies for Advanced Study, Longman, London.

TSCHÁ, M.C., SALES, M.F. \& ESTEVES, G.L. 2002. Tiliaceae Juss. No estado de Pernambuco, Brasil. Hoehnea 29(1):1-18.

VARJÃO, R.R., JARDIM, J.G. \& CONCEICÃO, A.S. 2013. Rubiaceae Juss. de Caatinga na APA Serra Branca/Raso da Catarina, Bahia, Brasil. Biota Neotropica. 13(2): http://www.biotaneotropica.org.br/v13n2/en/abstract ?inventory+bn00313022013 (last access in 12/08/2017).

VELLOSO, A.L. SAMPAIO, E.V.S.B. \& PAREYN, F.G.C. 2002. Ecorregiões propostas para o bioma Caatinga. Associação Plantas do Nordeste, Recife.

VICENTINI, A. \& SILVA, J.A. DA. 1999. Sterculiaceae. In Flora da Reserva Ducke (J.E.L.S. Ribeiro, et al. eds.). Flora da Reserva Ducke. Guia de identificação das plantas vasculares de uma floresta de terra-firme na Amazônia Central. Instituto Nacional de Pesquisa da Amazônia, Manaus. p. 265-267.

VIEIRA, D.D., MELO, J.I.M. \& CONCEIÇÃO, A.S. 2015. Boraginales Juss. ex Bercht. \& J.Presl in the Ecoregion Raso da Catarina, Bahia, Brazil. Biota Neotrop. 15(3):1-17. http://dx.doi.org/10.1590/1676-0611-BN-2014-0201 (last access in 13/04/ 2018).

VOGEL, S. 2000. The floral nectaries of Malvaceae sensu lato - a conspectus. Kurtziana 28:155-171. 